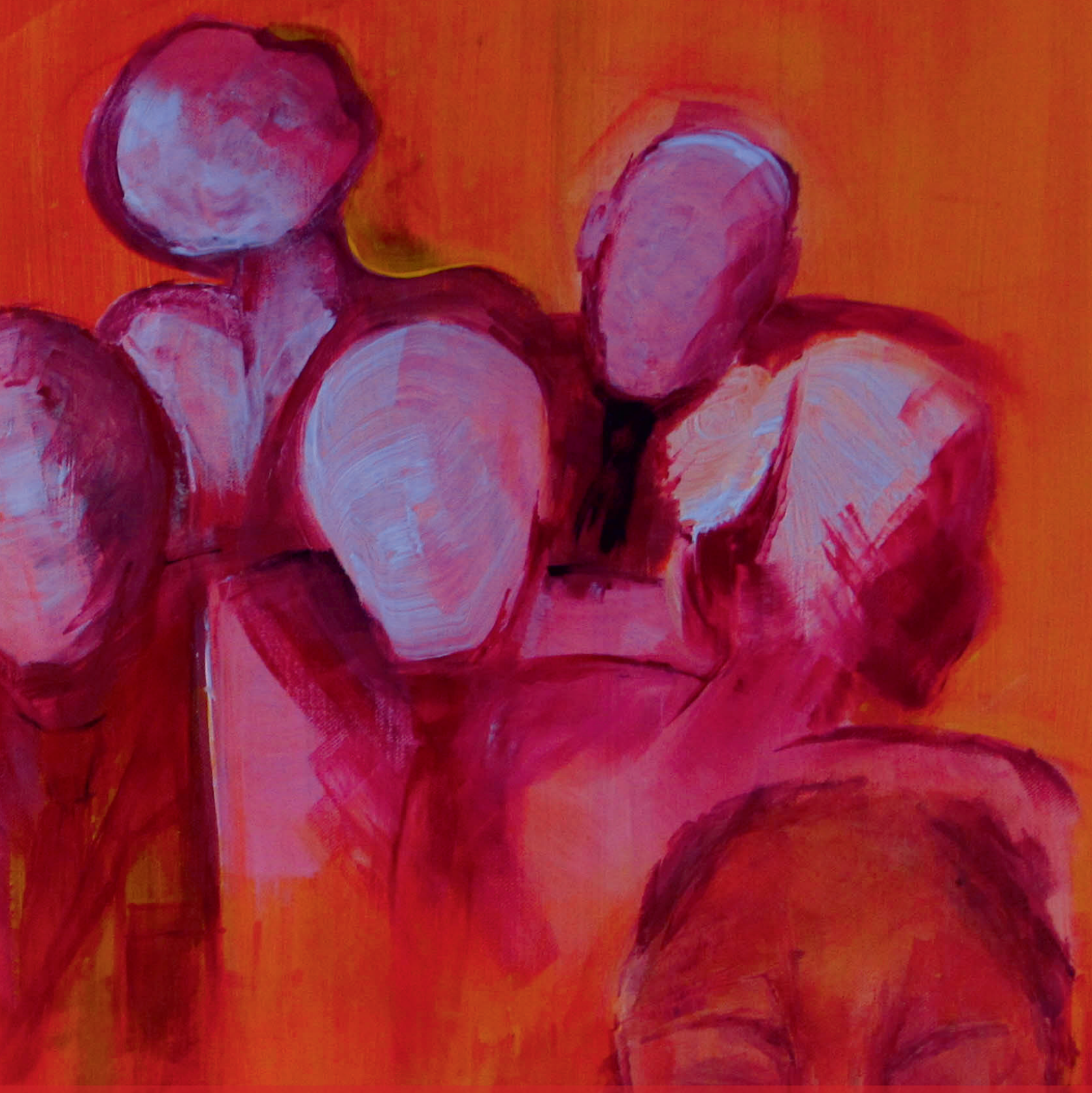

\title{
Teaming Teachers
}

Exploring factors that influence effective team functioning in a vocational education context 


\section{TEAMING TEACHERS}

EXPLORING FACTORS THAT INFLUENCE EFFECTIVE TEAM FUNCTIONING IN A VOCATIONAL EDUCATION CONTEXT 
This research project was funded by Max Goote Leerstoelenfonds.

Truijen, K.J.P.

Teaming Teachers

Exploring factors that influence effective team functioning in a vocational education context

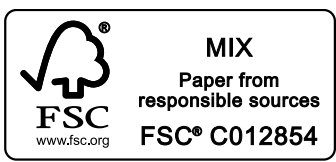

Thesis University of Twente, Enschede.

ISBN: 978-90-365-3334-8

DOI: $10.3990 / 1.9789036533348$

Cover by Annie Truijen

Bookdesign and printed by Gildeprint Drukkerijen, Enschede, the Netherlands. 


\title{
TEAMING TEACHERS
}

\section{EXPLORING FACTORS THAT INFLUENCE EFFECTIVE TEAM FUNCTIONING IN A VOCATIONAL EDUCATION CONTEXT}

\section{PROEFSCHRIFT}

\author{
Ter verkrijging van, \\ de graad doctor aan de Universiteit Twente, \\ op gezag van de rector magnificus, \\ prof. dr. H. Brinksma, \\ volgens besluit van het College voor Promoties \\ in het openbaar te verdedigen \\ op woensdag 21 maart 2012 om 14.45 uur
}

door

Karin Johanna Petronella Truijen

geboren op 18 maart 1982

te Horst 
Promotoren: prof.dr. P.J.C. Sleegers en prof.dr. A.F.M. Nieuwenhuis Assistent promotor: dr. M.R.M. Meelissen

Dit proefschrift is goedgekeurd door de promotoren en assistent promotor. 


\section{Samenstelling promotiecommissie}

Voorzitter: $\quad$ prof.dr. K.I. van Oudenhoven- van der Zee Universiteit Twente

Promotoren: prof.dr. P.J.C. Sleegers Universiteit Twente

prof.dr. A.F.M. Nieuwenhuis Open Universiteit Heerlen

Assistent promotor: dr. M.R.M. Meelissen

Leden: $\quad$ prof.dr. J.W.M. Kessels Universiteit Twente

prof.dr. J.C. Looise Universiteit Twente

prof.dr. J.M.G. Brekelmans Universiteit Utrecht

dr. J.W. Luyten Universiteit Twente

Referent: dr. M. van Woerkom Universiteit van Tilburg 



\section{Contents}

Chapter $1 \quad$ General Introduction

Chapter 2 What makes teacher teams in a vocational education context effective?

A qualitative study

Chapter 3 Conceptualizing Routines as a source of Team effectiveness.

Examining the relationship between Routines and Team effectiveness

Chapter 4 The mediating role of Group efficacy in the relationship between Routines and Team effectiveness

Chapter 5 Effects of Transformational leadership and Routines on Group efficacy and Team effectiveness. A comprehensive model

Chapter 6 General Discussion

References

Summary in Dutch (Samenvatting)

List of publications (Publicaties en presentaties) 

"Life is like riding a bicycle. To keep your balance you must keep moving"

-Albert Einstein- 



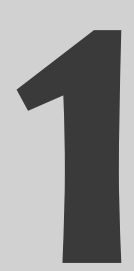

General Introduction 
$\frac{1}{ \pm}$
$\stackrel{ \pm}{0}$
$\frac{0}{U}$
$\frac{0}{U}$
12 
Secondary vocational schools in the Netherlands are increasingly reshaping the delivery of the instruction and coaching of their students into a team-based organisational structure. Instead of being responsible for instruction in one or two subjects, teachers are part of an interdisciplinary team, in which they have to collaborate with other team members to teach students the necessary competences to become a professional in their chosen occupation. As secondary vocational schools are required to design all their courses based on ComptenceBased Education ( $C B E)$, these teacher teams are expected to be essential to ensure the implementation of $C B E$, so as to improve the quality of education. $C B E$ has its origin in the European ambition to become the most dynamic and competitive region in the world (Lisbon, 2000). In order to attain this goal, the Dutch government decided to improve the level of its vocational education by changing the way teaching and learning was organised, and assumed that CBE would contribute highly to this improvement. CBE implies an integration of different subjects within courses, and an integration of theory and practice (Ritzen, 2004). Vocational qualifications should consist not just of specific skills, but of 'competencies' as well: the qualifications needed to practise a certain profession in an actual work situation (Basoski, Van den Hoek, \& Massier, 2009; Biemans, Nieuwenhuis, Poell, Mulder, \& Wesselink, 2004; Van der Meijden, Westerhuis, Huisman, Neuvel, \& Groenenberg, 2009; Van Merriënboer, Van der Klink, \& Hendriks, 2002). Effective CBE requires the synergy of teachers from different disciplines. Teachers are therefore organised into interdisciplinary teams, responsible for the educational programme of one or more particular subgroups of students.

Moreover, research emphasises that the introduction of teacher teams could stimulate the professional development of teachers (Pelkmans \& Smit, 1999; Van de Venne, Felix, \& Vermeulen, 2001). It is assumed that working intensively together with colleagues stimulates the learning and sharing of knowledge and expertise (e.g., Newmann, King, \& Youngs, 2000). Research also demonstrates that, by working in teacher teams that have a certain level of authority and responsibility, educational developments can be dealt with more efficiently than in traditional, hierarchical educational settings (Porter-O'Grady \& Wilson, 1998). Hierarchical educational settings are characterised by the centralisation of authority, which might constrain the organisation's flexibility. Within a team-based organisational structure, decisions and authority no longer rest with a small number of key figures that are high up in the organisation's hierarchy. Rather, there is a flatter hierarchy, in which leadership is much more evenly distributed throughout the educational setting, which allows for better adaptability and continual adjustment (Gronn, 2000; Mayrowetz, Murphy, Louis, \& Smylie, 2007; Spillane, Halverson, \& Diamond, 2001). 
In spite of the appeal of forming teacher teams in vocational education, studies indicate that teams in educational settings are not easily implemented (e.g., Crow \& Pounder, 2000; Scribner, Sawyer, Watson, \& Myers, 2007; Somech \& Drach-Zahavy, 2007). For example, research shows that the level of participation in and contribution to the completion of a team task can be unevenly distributed among teachers. The reason for this is a lack of support for teamwork. This is a recurrent problem with teams in schools, because schools are traditionally hierarchically structured, and teaching has always been characterised by a high degree of autonomy in the exercise of the profession (Clement \& Vandenberghe, 2000). Traditionally, contact between teachers was rather limited, because they performed most of their work (teaching a class) independently. As a result, teachers mostly developed their careers independently of their colleagues (Somech \& Bogler, 2002). Consequently, working in teams requires a kind of 'cultural shift' for both management and teachers. The degree of autonomy and joint responsibility for team results is new to many teachers. Teamwork demands a much more intensive form of cooperation and involvement than most teachers have been used to in the past.

Although teams and team functioning have been the focus of researchers from different disciplines, and have been studied from different perspectives (for overviews, see, e.g., Guzzo \& Dickson, 1996; Mathieu, Maynard, Rapp, \& Gilson, 2008; Stewart, 2006), studies on the conditions that support or limit the successful implementation of teacher teams are still scarce. The results of this dissertation are expected to provide a deeper understanding of the mechanism that underlies the ability of teacher teams to function effectively. The starting point for this is an Input-Process-Outcome framework, which is explained further in the next section.

\section{A model of teacher team effectiveness}

The Input-Process-Outcome (IPO) framework has been the foundational conceptual framework for a great number of studies from various disciplines on team effectiveness, including studies on teacher teams (e.g. Somech \& Drach-Zahavy, 2007). The framework focuses on the input and antecedent factors that enable members' interaction. These include individual team member characteristics (e.g. competencies, personalities), team-level factors (e.g. task structure, external leader influence), and organisational and contextual factors (e.g. organisational design features, environmental complexity). These various input factors combine to drive team processes. Process factors describe the interaction between team members, for instance information exchange. 
In order to find input and process factors that are related to effective team functioning, it is necessary to examine first what is considered to be team effectiveness in the vocational education context. In the literature, team effectiveness is often seen as a construct, consisting of a number of aspects (Hackman, 1983; Kozlowski \& Ilgen, 2006). In general, researchers have assessed team effectiveness based on three categories of criteria: (a) team performance (e.g., standard of quality), (b) social criteria (e.g., the capability of team members to work together in the future: viability) and (c) personal criteria (e.g., team members' personal wellbeing) (e.g., Hackman, 1990). The inclusion of social and personal criteria in a definition of effectiveness is important, because Hackman argues that a team that performs its task well, but is not able to work together in the future, is not an effective team. The stability of a team in which members are able to work well together and feel committed to the team is also an important indicator of effectiveness. This is also of importance for teams within vocational education in the Netherlands. Teams within vocational education aim to coach and help students in their individual development (performance), and these teacher teams also have the ability to continue working together or, in other words, stay together over the longer term (viability). Therefore, in this study, performance and viability will be the two outcome factors to measure team effectiveness.

Research on team effectiveness in non-educational contexts has resulted in an extensive list of input and process factors that may potentially influence team effectiveness. The identification of factors relevant to a vocational educational context is one of the aims of the qualitative study described in this dissertation. Both research literature and the results of the qualitative study resulted in a selection of predictive factors for team effectiveness in a vocational educational context. Central to our team effectiveness model is one team process factor: group efficacy, which represents a motivational process. Group efficacy is "a group's collective estimate regarding the group's ability to perform a task objective" (Gibson, 2001, p. 790). As mentioned earlier, in vocational education, where tasks were often structured for the individual teacher, the transfer to teamwork often implies a process of building motivation for teamwork. Group efficacy is the collective belief of a team that it can be effective (Guzzo, Yost, Campbell, \& Shea, 1993). Group efficacy can therefore be an important construct for teacher teams. Given that group efficacy can motivate teachers to perform better as a team, the question then is how group efficacy develops, and thus, what are the potential antecedents (input factors) that may enhance group efficacy and, in turn, affect team effectiveness.

In this study, we chose to focus on routines and transformational leadership as potential input factors. Routines and transformational leadership were chosen because, in the qualitative study described in this dissertation, they were found to be essential factors for promoting 
teamwork in vocational education. Moreover, the two variables have recently received much theoretical attention as the potential antecedent of group efficacy and team effectiveness (e.g., Becker, 2008; Dionne, Yammarino, Atwater, \& Spangler, 2004; Lim \& Ployhart, 2004). Routines can be defined as 'recurrent interaction patterns' (Becker, 2005). Recurrent interaction patterns describe what members do in a particular situation. They capture the way in which the tasks in a team are typically accomplished. In other words, routines describe what is done by whom and why. For this reason routines seem to be important for teachers in vocational education, as they enable teachers to form expectations and make appropriate decisions about interactions, leading to greater coordination between teachers to complete team tasks. In addition to routines, scholars have recently emphasised the importance of transformational leadership on group efficacy and team effectiveness (Walumbwa, Wang, Lawler, \& Shi, 2004). Transformational leaders have the ability to enhance the followers' collective motivation and confidence, by elevating the salience of the group and its capabilities, while also supporting followers in achieving their collective goals (Bass \& Avolio, 1994). Thus, in this study, we expect that routines and transformational leadership will enhance group efficacy (Bandura, 1997), and that these positive beliefs about the team will, in turn, foster team effectiveness (Lindsley, Brass, \& Thomas, 1995; Shea \& Guzzo, 1987).

\section{Overview of the thesis}

Using both qualitative and quantitative research methods, this study tries to examine the influence of routines and transformational leadership on group efficacy and team effectiveness in secondary vocational education in the Netherlands, in Vocational Education and Training (VET) colleges. First, a qualitative study was conducted. Next, insights from the literature and the qualitative study were used to develop a conceptual framework for the quantitative studies.

The starting point of this study was to address the question of how team effectiveness in a vocational education context can be defined. In the second chapter, we report on interviews with 28 managers from a VET college, in order to find factors specific to the vocational education context that are related to effective team functioning. The results of this qualitative study were used to develop our conceptual team effectiveness model for the quantitative studies.

The third chapter contributes to research on team effectiveness, by exploring the value of routines for team effectiveness. More specifically, this study tries to find empirical evidence for the presumed importance of routines for team effectiveness, by analysing their direct effect on team effectiveness. In order to test the relationship, a survey was undertaken in two VET colleges, where data were collected from 1624 members of 289 teams. Furthermore, this study tackles the fundamental problem in the routines literature of conceptualising the concept of routines for empirical research. Despite a growing body of research which has 
contributed to the understanding of the concept of routines, researchers employ different perspectives to conceptualise routines. This study contributes to the knowledge base of routines by providing a conceptualisation for applying the concept of routines in empirical research.

Chapter 4 focuses on a cross-level model, which links routines with group efficacy and team effectiveness. In order to test this model, data were used from a survey of 450 members of 50 teams in a VET college. The data were analysed by Multilevel Structural Equation Modelling (MSEM): a new technique to study the complex relations between individual level variables and team level variables in a single research model, which also takes into account the multilevel structure.

In the fifth chapter we elaborate the relationship between routines, group efficacy and team effectiveness further by examining the role of transformational leadership. This comprehensive conceptual framework of team effectiveness was tested using data from 450 members of 50 teams in a VET college.

Chapter 6 concludes with the major results of the four studies. It reflects on the implications of this study at conceptual, methodological, empirical and practical levels. Finally, it discusses challenges and future directions for the research related to factors facilitating effective teamwork in secondary vocational education in the Netherlands. 



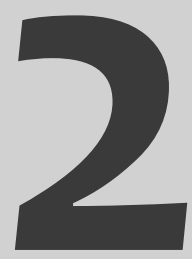

\section{What makes teacher teams in a vocational education context effective? A qualitative study}

${ }^{1}$ This chapter is a modified version of the manuscript Truijen, K.J.P., Sleegers, P.J.C., Meelissen, M.R.M, \& Nieuwenhuis, A.F.M. (resubmitted. Journal of Workplace Learning). What makes teacher teams in a vocational education context effective? A qualitative study. 


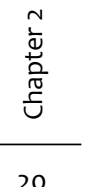


In the Netherlands, Competence-Based Education (CBE) is the leading paradigm on the innovation agendas of schools for vocational education, at the level of both policy-making and educational practice (Biemans, Nieuwenhuis, Poell, Mulder, \& Wesselink, 2004; Van der Sanden, De Bruijn, \& Mulder, 2003). The Dutch government concluded that vocational education graduates did not have enough practical skills to perform adequately in the work situation (Streumer \& Van der Klink, 2004). CBE is expected to enable students to acquire the competencies needed in their future professions, in order to better prepare students for the current and future labour market (e.g., Basoski, Van den Hoek, \& Massier, 2009). Effective CBE requires the synergy of teachers from different disciplines. Teachers are therefore organised into interdisciplinary teams, responsible for the educational programme of one or more particular subgroups of students. These groups consist of students enrolled in a programme for a specific field of work, such as mechanical engineering or nursing. The teacher teams are expected to function relatively autonomously in deciding how to conduct the training of a group of students. The teacher teams usually each have a manager (i.e. head of department) as their formal executive. In most cases, the manager is responsible for putting the teams together, connecting the teams' goals with the public assignment of the Vocational Education and Training (VET) college and creating optimal working conditions for the teams to work effectively.

However, studies of teacher teams show that it is not easy to implement teams in educational settings (Crow \& Pounder, 2000; Scribner, Sawyer, Watson, \& Myers, 2007; Somech \& DrachZahavy, 2007). Working in teams requires not only a change in organisational structure, but also a kind of 'cultural shift' for both management and teachers. Teamwork demands a much more intensive form of cooperation and involvement than most teachers have been used to. Traditionally, there was only limited contact between teachers, as they carried out most of their work (teaching a class) alone. Consequently, teachers tended to develop their careers independently of their colleagues (Somech \& Bogler, 2002).

In this study, we interviewed 28 managers from a VET college, in order to find factors specific to the vocational education context that are related to effective team functioning. We examined what is considered to be team effectiveness and what specific factors are considered to influence the effective functioning of teams. We interviewed managers, because they are responsible for the functioning of the teacher teams. We first conducted a review of the literature on team effectiveness. This review was not intended to provide a complete and final overview of theories and empirical studies on teacher team effectiveness. Rather, the review was meant to present a framework on which we would rely in our qualitative study, to study the main potential factors that influence team effectiveness. 


\section{Teacher team effectiveness models}

The Input-Process-Outcome (IPO) framework has been the foundational conceptual framework for very many studies from a number of disciplines on team effectiveness, including studies on teacher teams (e.g., Somech \& Drach-Zahavy, 2007). The model focuses on the inputs or antecedent factors that enable members' interactions. These include individual team member characteristics (e.g., competencies, personalities), team-level factors (e.g., task structure, external leader influence), and organisational and contextual factors (e.g., organisational design features, environmental complexity). These various input factors combine to drive team processes. Process factors describe the interaction between team members, for instance information exchange. As regards the effectiveness (outcomes) of teacher teams, researchers have applied many criteria to define the effects of the input and process factors on team effectiveness (Crow \& Pounder, 2000; Somech \& Drach-Zahavy, 2007; Van den Bossche, 2006). In general, researchers have evaluated team effectiveness on the basis of three categories of criteria: (a) team performance (e.g., standard of quality), (b) social criteria (e.g., capability of team members to work together in the future: team viability), and (c) personal criteria (e.g., team members' personal well-being) (e.g., Hackman, 1990). It is important to include social and personal criteria in a definition of effectiveness, because Hackman argues that a team that carries out its task well, but is unable to work together in the future, is not an effective team. The stability of a team where members are able to work together well and feel committed to the team is also an important indicator of effectiveness. Moreover, team innovation is often taken as a dimension of team effectiveness in educational settings (Somech \& Drach-Zahavy, 2007). Team innovation is the introduction or application within a team of ideas, processes, products or procedures that are new to the team and that are designed to be useful (West, 2002).

In the IPO framework, team effectiveness is influenced by both input and process factors. Building on the general IPO framework, Hackman and Oldham (1980) proposed that the level of effort, knowledge and skills, and performance strategies are process criteria of effectiveness. Several features of the team and its context can lead to improvements in these process criteria. In particular, Hackman and Oldham proposed three classes of input variables: organisational context factors (e.g., the reward, education and information system), work design factors (e.g., the structure of the group task, the composition of the group and group norms), and healthy interpersonal process factors. Conley, Fauske and Pounder (2004) used Hackman and Oldham's model from the broader organisational literature to study interdisciplinary teams in middle schools. Findings indicate that two fundamental variables, knowledge and skills applied to the work and performance strategies, are core mediators (processes) in the model. These results suggest that team effectiveness is influenced by the degree of specialised skill and knowledge members bring to bear on tasks and on performance strategy. Two healthy interpersonal process factors were also found to have 
direct effects on perceptions that teaming had improved teaching and learning. Specifically, weighting/balancing inputs and implementing strategies have a direct effect on teaching and learning effectiveness. Conley, Fauske and Pounder show that, as in previous research (Crow \& Pounder, 2000), teachers who perceive their team to be highly participatory and team members to be comfortable sharing ideas report favourable team outcomes. Recently, Somech and Drach-Zahavy (2007) have found that frequency of meetings and functional heterogeneity (input factors) are positively associated with the four interaction processes: exchanging information, learning, motivation and negotiation, which, in turn, lead to team innovation. Moreover, their study indicates that frequency of meetings is positively associated with exchanging information, which, in turn, enhances team performance.

In this study, we have also chosen to use the general IPO framework as a guide to our qualitative study, to categorise factors important for team effectiveness in a vocational education context. We examined what is considered to be team effectiveness and what input and process factors are mentioned in that respect.

\section{Method}

\section{Procedure and sample}

The study was conducted in a VET college in the Netherlands. This VET college provides vocational education and training in about 20 different branches, covering the following vocational areas: Engineering and Technology, Care, Health, Economics, Trade, Sports, ICT, Catering and Tourism, Arts and Design, and Fashion Textiles. At present, the VET college chosen for this study has more than 22,000 students and about 2000 employees. The school was in its second year of the implementation of CBE using teacher teams. Teams were organised around groups of students. These are students enrolled in a programme for a specific field of work (vocational course). The teams included teachers from different disciplines. We interviewed 28 managers, who were responsible for the teams from different sectors and departments. Each manager was interviewed individually. The managers interviewed were reassured that the interviews were unrelated to any form of performance evaluation, and that their reports would only be used for scientific purposes. The interviews followed a semistructured format, based on questions arising from the components of the IPO framework of McGrath (1964). The interviews focused on managers' perceptions of the effectiveness criteria of teams (outcomes) and the input and process factors. On average, the interviews in this study took between 45 minutes and one hour. All interviews were tape-recorded and transcribed verbatim. The textual data were analysed using Atlas.ti: a workbench for the qualitative analysis of textual data. The first author categorised the transcripts into the three broad foci of attention: input factors, process factors and outcomes. After categorising all the transcripts, the first author trained a student-assistant to code and categorise together 
the transcripts further. When the student was not sure about a code, she discussed it with the first author of this paper. After coding all the transcripts, we calculated the inter-rater reliability of the coding. We compared $60 \%$ of the transcripts coded by the student-assistant with the coded transcripts of the first author. The Cohen's Kappa was found to be 0.8 , which in general is regarded as highly reliable (Miles \& Huberman, 1994). The next section presents our findings.

\section{Results}

\section{Team effectiveness}

The interviews reveal that team effectiveness consists of more than one aspect, as previously also shown in the literature. In their definitions, managers tended to focus on three elements of team effectiveness: performance, viability (members' ability to work together) and team innovation.

Firstly, managersindicated aspects of team effectiveness that are based on performance measures. In terms of team performance, managers mentioned aspects that are relevant, not only to the teams in question but also to the entire VET college. Managers mentioned for example: "Returns concerning student numbers and absence rates are substantial", "Number of graduates" and "Student and company satisfaction". Managers also spoke of aspects concerning the quality of the primary process. "The primary process is important"; "We should be explicit in what we consider to be good education"; "Think about what competency-based education entails, then shape it and adjust it where needed". Moreover, managers emphasised that teams within vocational education should coach and help students in their individual development. On this topic, managers said the following: "Supervise students on their way to a diploma".

Secondly, in addition to the above aspects of performance, comments in regard to team effectiveness also focus on viability. The analysis shows that $50 \%$ of the managers stressed the importance of committed members or, in other words, the ability of team members to work together. Managers mentioned that an effective team is a team that works together smoothly. One manager said: "What will always be most important is that people working in teams have to be willing and able to work together; a group's chemistry is vital".

Finally, managers also spoke of aspects concerning team innovation. The managers felt it was very important for teams to keep track of educational developments. Other aspects that were touched upon in the light of these developments were taking the initiative and searching for new ideas and 'looking around'. However, managers did notice that teams tended to have difficulty being innovative. As one manager put it: "Teams rely heavily on traditional education with a veneer of competency-based education". This quote shows that teacher teams may find it difficult to implement new forms of education. 
Thus, in accordance with the literature, the interviews show that team effectiveness within vocational education consists of a combination of aspects that concern team performance, viability and team innovation.

\section{Influences on Team Effectiveness}

Input

From the interviews, a number of input factors can be deduced. The interviews with managers show that the size of a team is important for team effectiveness. First of all, managers indicated that most teams consisted of six to ten members. The majority of managers said that they preferred a small team (6-10 members) to a large one. One manager indicated: "If a team is too big, some teachers will withdraw. A team consisting of more than ten people is too large, and will result in teachers getting lost in the crowd ". Apart from that, the managers argued that it was not merely group size that was important for an effective team, but team members' characteristics as well: "In fact, it's the type of teacher that determines a group's effectiveness". It was considered an advantage when team members had the same educational view and motivation, and when there was an equal distribution of younger and older, and male and female team members. Younger teachers were said to adopt educational innovations more easily, although one manager did mention: “... you shouldn't be too harsh on older teachers, since they bring in a certain calm and expertise - so that's the other side of the story".

Furthermore, the analysis of interviews reveals that leadership in a team is an important theme. The managers indicated that, although teams were expected to assume a certain responsibility for managing themselves and their tasks, they did not always do so. The analysis shows that $75 \%$ of the managers in this study mentioned that a team could not manage itself without a leader. The managers proposed that a more informal leader should arise from the team and take an active stance, but this did not always happen: "When a team lacks a natural leader, it's impossible for a bunch of teachers to become self-reliant. Then it will just be five or six people sitting together, cackling - that would still be a chaotic structure. There has to be some kind of leadership, somehow". Apart from the importance of leadership for effective team functioning, managers also mentioned clear tasks and a common goal within the team. According to the managers, everyone should know what their team is supposed to achieve collectively. One of the managers explained: "Cooperation can only be really successful when all work towards the same goal - so when everyone has the same goal".

Finally, the interviews with managers made it clear that a team cannot function properly without effective working relationships. According to the managers in this study, teachers have to know each other's roles and responsibilities, before they can work as a team. To have knowledge of the roles and responsibilities of members of a team, and to know how they will respond, helps team members in effective team work. At the same time, managers 
indicated that building these working relationships was difficult for teacher teams, as a result of limited opportunities to interact. Managers indicated that the working environment should be arranged in a way that encourages interaction between team members. Managers were positive about the working environment when team members were offered workplaces in close proximity to each other, as well as areas in which the team could work together. Managers were dissatisfied with the workplaces when these were far apart, since that was said to hinder communication. The managers stressed the importance of formal meetings as well as meetings on a more informal basis (for example communication at the coffee machine) for the effective functioning of teams. According to the managers, teachers might otherwise have a tendency to stay within their own 'kingdom'. So, the managers in this study were almost unanimous in believing that having adequate working relationships is very important for effective team work. To enable their teams to develop working relationships, managers preferred workplaces in close proximity to each other, in order to stimulate interaction between team members.

\section{Processes}

In the literature, processes are described as team members' interactions aimed at the accomplishment of tasks. When we look at the quotes derived from the interviews with managers, most of these concern the way managers would prefer their team members to work together. Over three-quarters of the managers who were interviewed mentioned aspects that can be classified under self-management. When discussing self-management, they spoke of the level of a team's independence necessary for good education and to a certain extent 'for making decisions and solving problems autonomously. A manager said for example: "A well-functioning team takes up tasks itself, and doesn't wait for me, the manager, to say so". The majority of managers indicated that they were satisfied with their team's level of independence concerning teaching. However, the managers did indicate that when a problem arose, all eyes turned to the manager, whereas the focus should be on solving the problem themselves: "All they really want to do is complain to me and have me take it from there".

In addition to self-management, managers indicated that feedback is also important in order for teams to cooperate properly. Managers indicated that when things go wrong, teachers should address each other's shortcomings, and stick to the agreements that had been made. For example, most of the managers wanted team members to confront each other about their behaviour. It is important for managers that teachers correct each other's behaviour by providing feedback. However, the interviews prove that this is not always the case. As a manager put it: "It will never be easy for teachers to criticise each other's behaviour. However well they may be working together, distributing tasks, and however informal and friendly their contact may be, it's still tough to go up to someone and say, 'Hey, I don't think 
you did your job"”. Another manager, on his teams: "The amicable nature of their cooperation makes it hard for teachers to admit, 'I don't feel you did very well on this or that'”.

\section{Conclusion and discussion}

In secondary vocational education in the Netherlands, competency-based education is being implemented in all VET colleges, calling for intensive collaboration between teachers. Many VET colleges set up teacher teams that are responsible for training and qualifying groups of students. In this study, we interviewed 28 managers, in order to find factors specific to the vocational education context that are related to effective team functioning. We examined what is considered to be team effectiveness and what input and process factors are mentioned in that respect. The previous description of the results can be summarised in terms of the key findings regarding input, processes and outcomes. Table 1 presents these findings.

\section{Table 1}

Summary of Findings

\begin{tabular}{|c|c|c|}
\hline Input & Process & Team effectiveness (outcomes) \\
\hline $\begin{array}{l}\text { Team size: managers prefer } \\
\text { small teams (6-10 members). } \\
\text { Team composition: managers } \\
\text { prefer homogeneity of } \\
\text { educational view and } \\
\text { motivation, equal distribution } \\
\text { of younger and older, and male } \\
\text { and female members. }\end{array}$ & $\begin{array}{l}\text { Focus on the way managers } \\
\text { would prefer team members to } \\
\text { work together (cooperation): } \\
\text { self-management (importance } \\
\text { of certain level of autonomy) } \\
\text { and giving feedback. }\end{array}$ & $\begin{array}{l}\text { Team performance: managers } \\
\text { mention for example number } \\
\text { of graduates, satisfaction of } \\
\text { stakeholders such as students } \\
\text { and companies and quality of } \\
\text { primary process. }\end{array}$ \\
\hline $\begin{array}{l}\text { Leadership: managers indicate } \\
\text { the importance of an informal } \\
\text { leader in the team providing } \\
\text { guidance. }\end{array}$ & & $\begin{array}{l}\text { Viability: managers indicate } \\
\text { that it is important that a team } \\
\text { has committed members and } \\
\text { works together smoothly. }\end{array}$ \\
\hline $\begin{array}{l}\text { Team tasks: managers prefer } \\
\text { clear direction and common } \\
\text { goals in the team } \\
\text { Working relationships: } \\
\text { managers indicate the } \\
\text { importance of adequate } \\
\text { working relationship or } \\
\text { knowledge of members' roles } \\
\text { and responsibilities. }\end{array}$ & & $\begin{array}{l}\text { Team innovation: managers } \\
\text { indicate that it is important } \\
\text { to keep track of educational } \\
\text { developments. }\end{array}$ \\
\hline
\end{tabular}




\section{Towards a model of teacher team effectiveness}

The aim of this qualitative study is to find factors that play a role in the effective functioning of teacher teams in Dutch vocational education. In order to determine what factors influence team effectiveness, we have linked the results from our qualitative study to what we know about team effectiveness from the literature.

\section{Team effectiveness (outcomes)}

In line with the literature on team effectiveness, managers tended to focus on more than one aspect when defining team effectiveness (e.g., Hackman, 1983; Kozlowski \& Ilgen, 2006; Mathieu, Maynard, Rapp, \& Gilson, 2008; Zellmer-Bruhn \& Gibson, 2006). For example, Hackman (1983) states that team effectiveness can be subdivided into team performance on the one hand, and viability and team members' affective attitude on the other. In their definitions, managers tended to focus on the first two elements. They focused on performance and viability (members' ability to work together), but they also stressed the importance of following educational developments (i.e. team innovation). This study stresses the multifaceted nature of the concept of team effectiveness for the vocational education context. Even though team performance is the most prevalent indicator of team effectiveness (Cohen \& Bailey, 1997; Sales, Sims, \& Burke, 2005), this study shows that criteria such as viability and team innovation should not be discarded, in order to obtain a complete picture of team effectiveness.

\section{Input factors}

When managers were asked about the factors that influence team effectiveness, the first important input factor they stressed refers to the size of a team. According to the managers, an effective team consists of six to ten teachers. This is in line with the study into the effectiveness of teacher teams by Crow and Pounder (2000). They conclude that group size is important for team effectiveness. They argue that teachers prefer small teams (5-6 members) to larger ones (10 members or more) for coordination and planning reasons. Also, according to Hackman (2002), six members would be the ideal number. Hackman argues that members of larger teams waste a considerable amount of time on issues concerning for example planning. Moreover, the managers indicated that teachers in a team should share the same educational view, and a mix of young and older, male and female is preferred. Crow and Pounder show that teams with teachers who share a similar philosophy on education and are in the same phase of their careers have less difficulty planning, agreeing, deciding, coordinating and sharing activities. Still, the literature does mention certain advantages to teams consisting of people with different professional backgrounds, knowledge and skills. These teams will be more innovative than homogeneous teams (Paulus, 2000; Somech \& Drach-Zahavy, 2007; West, 2002), because the integration of diverse perspectives creates the 
potential for combinations of ideas from different domains. This is likely to produce creative ideas.

Furthermore, the managers also emphasised clear and common goals and leadership within the team as important conditions for a successful team. In his book 'Leading teams', Hackman (2002) underlines the importance of a clear goal. The determination of goals is often done in consultation with the team management. The extent of involvement of the manager in defining clear goals depends on the team's level of self-management. It is important for a manager to be aware of and anticipate a team's level of self-management. For example, when a team has been working together only for a short period of time, the manager will help in determining their direction. It is important for managers to realise that teacher teams do not just materialise and immediately start working together towards a common goal. For managers, it is vital to be aware of the developmental process teams have to go through, and it is important to be able to support their learning process and guide the teams through this process (Hackman, 2002). In the literature, this type of leadership is designated as transformational leadership (Avolio, Bass, \& Jung, 1999). Transformational leadership leads to a shared vision and trust within the team. When all team members are focused on a common goal, it may stimulate a team's development. Team members will reflect themselves on how best to carry out their work and team processes, which will eventually lead to better team performance (Schippers, Den Hartog, Koopman, \& Knippenberg, 2008). So, the role of the manager (executive) is crucial in the developmental process of teams (Stoker, 1999). Scribner, Sawyer, Watson and Myers (2007) state that a team that is left to its own devices will perform below par.

Finally, the managers indicated that having adequate working relationships and interaction between team members is very important for the teams. Research also shows that working relationships and interaction within teams are important for team functioning (e.g., Somech \& Drach-Zahavy, 2007; Klimoski \& Mohammed, 1994). From the organisational literature, it has been suggested that the routine concept is critical to the organising of group actions and interactions leading to effective team functioning (Becker, 2008). Routines also seem to be important for teachers in vocational education, as they enable teachers to form expectations and make appropriate decisions about interactions, leading to greater coordination between teachers to complete team tasks. Routines can be defined as 'recurrent interaction patterns' (Becker, 2005). Recurrent interaction patterns describe what members do in a particular situation. They capture the way in which the tasks in a team are typically accomplished. In other words, routines describe what is done by whom and why. Teachers in educational settings are typically isolated in their classrooms, with limited opportunity to interact with colleagues. Consequently, routines seem to be important for teachers in vocational education. Focusing on the operation of routines in teacher teams could provide us with a new and valuable approach to understanding the effective functioning of teacher teams. 


\section{Process factors}

When discussing process factors, the managers especially stressed a team's required level of self-management. The literature shows that when a team has at least the authority level of a self-managing team, this results in teachers' feeling a joint responsibility and becoming more motivated for team tasks (Crow \& Pounder, 2000; Conley, Fauske, \& Pounder, 2004; Hackman, 2002). Self-management has been suggested as a means of facilitating productive and motivated team behaviour in schools. However, the degree of autonomy and joint responsibility for team results is new to many teachers. The individualistic nature of teachers' work in the past has led to the development of personal responsibility and the authority of individual teachers in their own classes (Somech \& Bogler, 2002). Clement and Vandenberghe (2000) show that such an autonomous work structure is likely to impair teachers' willingness to participate in teamwork. So, in vocational education, where tasks were often structured for the individual teacher, the transfer to teamwork often implies a process of building motivation for teamwork. In the literature, this type of motivation is often referred to as group efficacy. Group efficacy is the collective belief of a team that it can be effective (Guzzo, Yost, Campbell, \& Shea, 1993). Group efficacy beliefs can mobilise the motivation, cognitive resources and courses of action needed to work effectively together in a team. Group efficacy can therefore be regarded as an important construct for teacher teams.

\section{Recommendation for future research}

This study focuses on the input, process and outcome factors of team effectiveness. The findings of this study have several important implications and directions for future research. Firstly, in accordance with the literature, the interviews show that team effectiveness within vocational education consists of several aspects (e.g., Hackman, 1983; Kozlowski \& Ilgen, 2006). Most studies into the effectiveness of teacher teams that have been conducted until now have focused on team performance. However, the interviews and the literature show that there are other aspects of team effectiveness, namely viability and team innovation (Hackman, 1983; Kozlowski \& Ilgen, 2006). Existing research on teacher teams can be extended by including viability or team innovation, in order to add considerably to the understanding of the effectiveness of teacher teams in vocational education in the Netherlands. Secondly, several team composition factors seem to be important for effective team functioning. For example, team size and team homogeneity are an issue. Future research which aims to determine effective team functioning in a vocational education context might therefore be further enriched by also integrating team composition factors. Thirdly, future research could shed light on transformational leadership that, when present, might increase the probability of developing effective teacher teams. Both research literature and the results of our qualitative study show that the role of the manager is crucial. In the literature, transformational leadership is regarded as an important factor, determining the 
development of self-management and, eventually, even team effectiveness (Stoker, 2007). To help a team become successful and facilitate its developmental process, it is important to have a transformational leader in a team. A transformational leader can stress a team's direction and thus motivate the team to go the extra mile (Avolio, Bass, \& Jung, 1999). Given the expected impact of transformational leadership on the effective functioning of teacher teams, future research could explore the relationship between transformational leadership and team effectiveness. Future research might also study the concept of routines in teacher teams. The routine concept offers an interesting perspective, since it is connected to the organising of group actions and interactions (Gersick \& Hackman, 1990). The managers who were interviewed stressed the importance of working relationships and stimulating interaction between teachers. In order to take the working relationships between teachers into account in future research, the concept of routines may be studied, as has been done in the organisational literature. Finally, when discussing process factors, the managers especially stressed a team's required level of self-management. Self-management requires team members' active involvement (Conrad \& Poole, 2002). In the literature, self-management is often related to a process of enhancing group efficacy beliefs. However, empirical support for the role of group efficacy, as one of the potential mechanisms that could explain the effective functioning of teacher teams, is still scarce. This kind of research could further help in developing an in-depth understanding of topics that are highly relevant to implementing effective teacher teams and building a team-based organisation. 



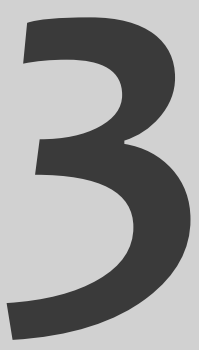

Conceptualizing Routines as a source of Team effectiveness. Examining the relationship between Routines and Team effectiveness ${ }^{1}$

${ }^{1}$ This chapter is a modified version of the manuscript Truijen, K.J.P., Sleegers, P.J.C., Meelissen, M.R.M., \& Nieuwenhuis, A.F.M. (submitted). Factors that influence effective team functioning in a vocational education context. 


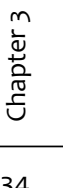


In recent decades, the increase in complex and ever-changing technology has transformed modes of doing business and the work processes in modern organisations. These forces have stressed the importance of a competent workforce and contributed to a belief that team work is the key to success for organisations (De Dreu \& Weingart, 2003; Sales, Goodwin, Burke, 2008; Van der Vegt \& Bunderson, 2005; Van Offenbeek, 2001). Given the growing importance of team-based work within organisations, the effectiveness of teams has become a major focus in research into organisational behaviour and performance (for overviews, see, e.g., Guzzo \& Dickson, 1996; Mathieu, Maynard, Rapp, \& Gilson, 2008; Stewart, 2006). One concept that is frequently overlooked, despite its potential to play a crucial role in improving team effectiveness, and hence organisational performance, is the concept of routines (Becker, 2008). Routines standardise and structure the actions of team members and therefore play an important part in optimising group functioning (Gersick \& Hackman, 1990). Although routines are often assumed to affect the effectiveness of work groups, there is still a dearth of empirical support for this assumption (Becker, 2005).

Drawing on the seminal work of Nelson and Winter (1982), routines have been discussed by many researchers from different disciplines (e.g. Becker, 2001; Cohen \& Bacdayan, 1994; Cohendet \& Lierena, 2003; Hodgson \& Knudsen, 2004; Lazaric, 2000; Pentland \& Feldman, 2008; Pentland \& Rueter, 1994). However, in spite of this, there has been little progress so far on an agreement as to what routines are, and therefore not much empirical progress in research on routines seems to have been made (Becker, 2005; Cohen \& Bacdayan, 1994). Becker and Lazaric (2009) emphasise that empirical research on routines is necessary and important, because empirical research can advance our understanding of routines, and thereby of how groups accomplish their tasks in organisations.

Given the expected impact of routines on team effectiveness, this study contributes to research on team effectiveness, by providing a conceptualisation for applying the concept of routines in empirical research, and by exploring the value of routines for team effectiveness. Our study proceeds in two main sections. We first provide a review of the relevant literature and discuss how routines may be related to team effectiveness. After reviewing the literature, we test the relationship between routines and team effectiveness, using data from 1624 members of 289 teams.

\section{Review of the literature}

\section{Team Effectiveness}

Although researchers have used many different indicators to study team effectiveness (for a review, see Mathieu, Maynard, Rapp, \& Gilson, 2008), two indicators of team effectiveness 
are often distinguished: team performance (i.e., quality and quantity of team outputs) and the affective reactions of team members (Mathieu et al., 2008; Zellmer-Bruhn \& Gibson, 2006). Research on team effectiveness and routines has mainly focused on performance, rather than on affective reactions to study team outputs (Becker, 2005). Despite the preference for team performance as output measure, the definition of this construct has still been 'less systematically addressed' by researchers (Ilgen, 1999, p.131). The main reason for this is that performance indicators are context specific. For instance, performance may refer to variables ranging from sales growth in a manufacturing organisation to the quality of social services provided in the field of social work. In order to deal with this problem, Hackman (1987) proposed defining team performance as the degree to which a team meets its goals and how well the output fulfils the team's mission. Following Hackman, many researchers have defined performance in relative terms and used perceptions of team performance to measure team effectiveness, with responses gathered as often from team members themselves as from team managers. In this study, we followed this line by measuring team effectiveness as members' perceptions of the performance of their team. In addition to team performance, Hackman (1983) argues that a team that performs its task well, but is not able to work together in the future, is not an effective team. The stability of a team in which members are able to work well together and feel committed to the team is also an important indicator of effectiveness (viability). Following Hackman (1990), we include both output factors (performance and viability) in our study, in order to measure team effectiveness.

\section{Routines}

By facilitating stable behaviour patterns and coordinated action, routines are assumed to foster team effectiveness (Becker, 2005; Gittell, 2002; March, 1991). Stable behaviour patterns enable members to form expectations and make appropriate decisions about interactions, leading to greater coordination. Well-coordinated work processes are expected to produce enhanced performance. However, empirical evidence regarding the relation between routines and team effectiveness is still missing. Until now, researchers on routines have seemed to be mainly concerned with the operationalisation of the concept of routines itself. While there is an ongoing debate among these researchers about the nature and components of routines, there seems to be an agreement that the concept of routines has two dimensions: a behaviour dimension and a cognitive dimension (Pentland \& Feldman, 2008). The first dimension addresses the recurrent behavioural patterns; routines are similar patterns of actions. Routines involve multiple employees, which indicates that routines do not refer to individual patterns of actions but to actions involving multiple members (Becker, 2005). This dimension has been associated with routines since the start of the research on routines (Becker, 2004). However, the problem with studying the behavioural dimension is that we have to measure recurrent behavioural patterns, which implies a definition of what 
constitutes the 'same' behaviour (Becker, 2005). According to Winter (1990), this poses 'serious conceptual and measurement challenges' (p. 279), because members can influence behaviour that is repeated, rather than replicate it like a robot. The question is therefore whether identical repetition is possible at all (Becker, 2005; Nelson \& Winter, 1982). For this reason, the cognitive dimension seems to be the appropriate dimension for empirical research on routines. The cognitive dimension addresses the knowledge which enables an employee to guide and refer to specific performances of a routine (Becker, 2008; Lazaric, 2000; Nelson \& Winter, 1982; Pentland \& Feldman, 2005). Although scholars support the notion that routines encode the knowledge of members, they employ different perspectives to conceptualise the construct of knowledge. As a consequence of this conceptual diversity, different interpretations exist about the nature of routines as knowledge. For some scholars, the cognitive dimension refers to rules and standard operating procedures which can lead to recurrent behavioural patterns. There are several problems with reducing the cognitive dimension of routines to rules and standard operating procedures. For example, March (1997) argues that a rule itself does not determine individual choices and behaviour. He argues that the behaviour required by the rule may be shaped through interpretation (March, 1997, p.20). Feldman (2003) too argues that it would be a mistake to operationalise the cognitive dimension (in her study, the ostensive part of a routine) as a standard operating procedure, because it is about the subjective understanding of members. Recently, researchers have defined the cognitive dimension of routines as dispositions to express the fact that routines are not behaviour; they are 'stored behavioural capabilities' (Hodgson, 2008; Hodgson \& Knudsen, 2004). Hodgson (2004) argues that the difference between understanding routines as behaviour patterns, or as cognition (in his study, defined as dispositions) is that, when triggered, the cognitive dimension is the causal mechanism that brings about behaviour ( $p$. 653). According to Hodgson and Knudson (2004), it is necessary to include the causes of recurrent behavioural patterns in a study on routines. In keeping with recent approaches, this study focuses on the cognitive dimension of routines. To measure the cognitive dimension of routines, we need to assess the causes of recurrent behavioural patterns or, in other words, what precisely enables a team member to perform routines. Although every situation might be different, and this might explain why most researchers define routines in a different way, what the definitions do have in common is that routines refer to interrelatedness (Dosi, Nelson \& Winter, 2000). Routines involve multiple employees. Routines are therefore phenomena that have to deal with a kind of interdependence. Interdependence refers to the degree to which the interaction and coordination of team members is required to complete tasks. Becker (2005) argues that interdependence is crucial for the performance of recurrent behavioural patterns. To explore the relationship between routines and team effectiveness, we measure the extent of interrelatedness of team members. Interrelatedness is not a onedimensional concept; it consists of members' perceived level of task-related and relational- 
related interdependence. Task-related interdependence refers to the pattern in which team members have to exchange information and resources to complete their collective tasks in teams. Relational-related interdependence refers to members' expectations about how to work well together as a team. This division is also consistent with team research, in which researchers argue that, in order to be successful, team members must not only need to perform task-related functions but also work well together as a team (McIntyre \& Sales, 1995). In this study, we expect that routines by measuring members' perceived interrelatedness, will be positively related to team effectiveness.

\section{Method}

\section{Research Design and Participants}

In order to test the relationships, a survey was conducted in two Vocational Education and Training (VET) colleges, where data were collected from 1624 team members. In terms of organisational structure, VET colleges are predominantly comprised of identifiable departments, such as Technology, Economics and Business, Health and Welfare, and Education. These departments are further subdivided into teams, consisting primarily of teachers and teaching assistants. They are both responsible for educational tasks, such as the coaching of students and guiding students' learning processes, curriculum planning, coordinating workplace learning and the assessment of students. Within each team, members must interact frequently, share information and coordinate, in order to perform their duties well (Cohen \& Bailey, 1997).

The questionnaires were mailed to team members' personal mailboxes in the period June to October 2008. Of the 3548 team members employed in 80 departments, comprising of 636 teams, about $46 \%$ (1624 individuals of 289 teams) returned the questionnaires. The average team size was 14 members $(S D=11)$, and the average age was 50 years $(S D=13.8)$. More women (55\%) participated in the study than men (45\%). Of the respondents, $82 \%$ held a Bachelor's degree or higher, $10 \%$ held a vocational education degree, and $8 \%$ had lower educational levels. The average duration of work experience within the VET colleges was 16 years $(S D=9 \cdot 3)$.

\section{Measures}

Dependent variable: team effectiveness

In order to measure team effectiveness, we measured team members' perceived team performance and viability. The five-item scale of Zellmer-Bruhn and Gibson (2006) was utilised to measure team performance. The following are examples of items from this scale: "This team achieves its goals" and "This team serves the purpose it is intended to serve". The Cronbach's alpha for this scale was .89. We used the items from the 'commitment 
to the group' scale of Ellmers, Kortekaas and Ouwerkerk (1999) to measure viability. The scale consisted of three items: "I would like to continue working with my group", "I dislike being a member of my group" and "I would rather belong to another group". The reliability (Cronbach's alpha) of this scale was .86. For both scales a five-point Likert scale, indicating the amount of agreement (1=totally disagree to $5=$ totally agree), was used.

Independent variable: routines

To study routines as cognition, we used two scales to assess members' perceived interrelatedness in the team by measuring members' perceived level of task-related and relational-related interdependence. Task-related interdependence was measured using four items from the 'task interdependence scale' of Van der Vegt, Emans and Van de Vliert (1998), which refer to the pattern in which team members have to exchange information and resources to complete their tasks in teams. An example item was: "To do my job, I need information from my colleagues". The Cronbach's alpha for this scale was .78. In addition to this taskrelated interdependence, we also added a second scale, consisting of three statements, to measure members' expectations about how to work well together as team (relational-related interdependence). As no scale for this dimension was available, we selected three items from the Work Scale (VBBA) of van Veldhoven and Meijman (1994), measuring ambiguities of work, and adjusted them, in order to assess relational-related interdependence. An example of an item from this scale is: "I know exactly what I can expect from my colleagues". The Cronbach's alpha for this scale was .79. For both scales a five-point Likert scale, indicating the amount of agreement (1=totally disagree to $5=$ totally agree), was used.

\section{Control variables}

Research has shown that length of time working together and team size are variables influencing team effectiveness (Crow \& Pounder, 2000; Guzzo \& Dickson, 1996; Kozlowski \& Bell, 2003). These variables were therefore included as control variables in our study. Length of time working together and team size were obtained from self-reports. Pre-structured questions were used to determine length of time working together ( $1=$ less than two years, $2=$ two to five years, $3=$ five to ten years, and $4=$ more than ten years).

Analysis

Although we handed out questionnaires to the individual team members, our measure of team performance was clearly aimed at the team level, and therefore the variable team performance in this study is expected to operate at team level (Klein \& Kozlowski, 2000). The first step in the analysis therefore was to find out if we could aggregate the data for this construct at team level. We used the intra-class correlation (ICC) to test whether the individual perceptions of team performance could be aggregated to the team level. We calculated 
the ICC (1) and ICC (2). The ICC (1) indicates the extent of agreement among ratings from members of the same team, whereas the ICC (2) provides an estimate of the reliability of the group means. James (1982) reported a median ICC (1) of .12. For our team-level variable: team performance, the ICC (1) is .18, indicating that a considerable part of the variance is between groups. For the ICC (2) a criterion of between .60 and .70 is sometimes used for aggregation. The ICC (2) is .60 for team performance. Based on the ICC, we decided to aggregate the individual team members' ratings of team performance to the team level.

Testing the model

We developed a cross-level model to describe and test the relationship between routines and team effectiveness at different levels of analysis (see Figure 1). Our cross-level model links two dimensions of routines - task-related interdependence and relational-related interdependence (individual level of analysis) - with team effectiveness (team performance at the group level of analysis and individual level viability). So, the model suggests that routines at the individual level of analysis influence team performance at a different - higher - level of analysis (see Figure 1). Until recently, multilevel methods were limited, because they could not accommodate a variable affecting another variable at a higher level and, as a result, each effect in the causal chain involves a variable affecting another variable at the same or lower level. This study used Multilevel Structural Equation Modelling (MSEM) to overcome this limitation. The MSEM approach has recently been introduced by Preacher, Zyphur and Zhang (2010) for addressing 'upward' effects within multilevel data. MSEM offers the possibility of testing these complex relations between individual level variables and team level variables in a single research model, which also takes into account the multilevel structure (individual nested in teams). Fit indices are necessary for the evaluation of MSEM. The fit of the MSEM model in the present study was assessed by means of the root mean squared error of approximation (RMSEA). The RMSEA is a widely applied model fit index, and is designed to assess how well the fitted model approximates the true model. With regard to this index, values below .08 are considered good (Hu \& Bentler, 1999). RMSEA values greater than .10 are considered to represent a poor fit. 


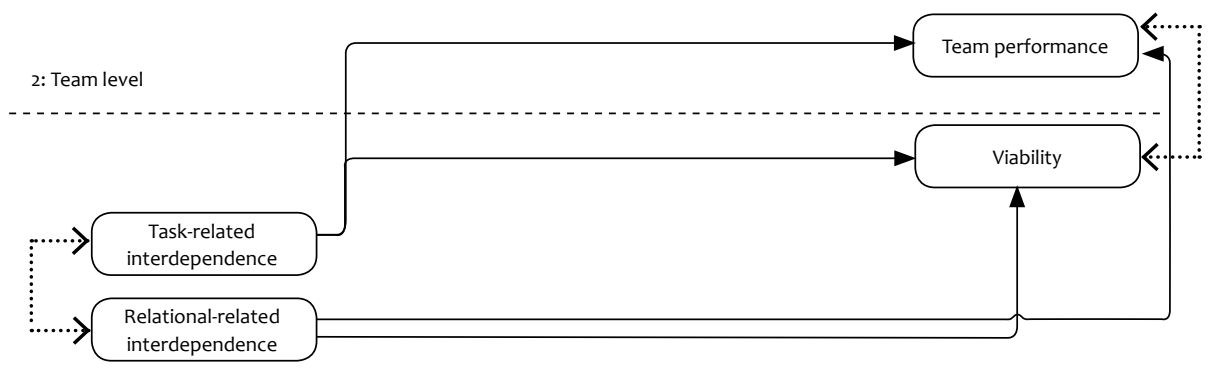

1: Individual level

\section{Figure 1}

Upper effect in a two-level model

\section{Results}

\section{Correlation analyses}

Table 1 shows the means and standard deviations of routines and team effectiveness and the correlations between the variables. Team members' agreements on the statements were relatively high, all cases above 3.00 on a five-point Likert scale. The highest scores were for perceived task-related interdependence (routines) $(M=3.60)$.

\section{Table 1}

Means, Standard Deviations and Correlations

\begin{tabular}{|c|c|c|c|c|c|c|c|c|}
\hline Variables & $\begin{array}{c}\text { Mean } \\
\text { (scale 1-5) }\end{array}$ & s.d. & 1 & 2 & 3 & 4 & 5 & 6 \\
\hline 1. Team performance & 3.51 & .32 & & & & & & \\
\hline 2. Viability & 3.38 & .51 & $.10 * *$ & & & & & \\
\hline $\begin{array}{l}\text { 3. Routine: task-related } \\
\text { interdependence }\end{array}$ & 3.60 & .58 & $.08 * *$ & $.11 * *$ & & & & \\
\hline $\begin{array}{l}\text { 4. Routine: relational- } \\
\text { related interdependence }\end{array}$ & 3.33 & .74 & $.19 * *$ & $\cdot 30 * *$ & $-.05 *$ & & & \\
\hline 5. Length of time together & 1.67 & .78 & $.14^{* *}$ & $.09 * *$ & .00 & $.14^{* *}$ & & \\
\hline 6. Team size & 13.63 & 10.95 & $-.08 * *$ & -.02 & $.07 * *$ & -.01 & $.06 *$ & \\
\hline
\end{tabular}

Note. $\mathrm{N}=1624$ To compute the individual-level Pearson correlations, the group's scores for team performance were assigned to each individual group member

$* \mathrm{p}<.05, * * \mathrm{p}<.01$ 
As expected, significant positive correlations were found for routines (task-related and relational-related interdependence) and team effectiveness (team performance and viability). Team size was negatively associated with team performance, indicating that the greater the number of members in a team, the less effective the team members perceived their team to be. Length of time together was found to be positively associated with team effectiveness.

\section{Multilevel structural equation analyses}

The test of the multilevel structural equation model showed that our proposed model fit the data well: RMSEA was <.08 (Hox, 2002; Hu \& Bentler, 1999). To avoid misspecification of the model, two team characteristics were entered as control variables in the analysis. The results showed that the control variable length of time working together had a positive effect on team effectiveness (team performance estimate $=.37, \mathrm{SE}=.11, p<.01$ and viability estimate $=.04, \mathrm{SE}=.02, p<.05)$. This means that the longer a team has been together, the more effective members perceive their team to be. Team size was found to be negatively related to team performance (estimate $=-.02, \mathrm{SE}=.01, p<.01$ ). This indicates that the more members a team contained the less effective the team would be. Thus, as expected, the two team characteristics were found to be related to team effectiveness (Guzzo \& Dickson, 1996).

Figure 2 shows the relationship between routines (task- and relational-related interdependence) and team effectiveness (team performance and viability). Results from the MSEM analyses suggest that both task- and relational-related interdependence were significantly related to team members' perceptions of team performance (task-related interdependence: estimate $=1.30, \mathrm{SE}=.35, p<.01$ and relational-related interdependence: estimate $=1.59, \mathrm{SE}=.25, p<.01)$. The more members perceive their tasks to be interdependent and the more they know what can be expected from each other, the more they perceive their team to be performing better. Furthermore, the results showed a significant positive relationship between routines and viability (task-related interdependence: estimate $=.11$, SE $=.03, p<.01$ and relational-related interdependence: estimate $=.22, \mathrm{SE}=.02, p<.01$ ). This means that in teams where members perceive routines (task-related and relational-related interdependence), team members show a stronger capability to work well together. 


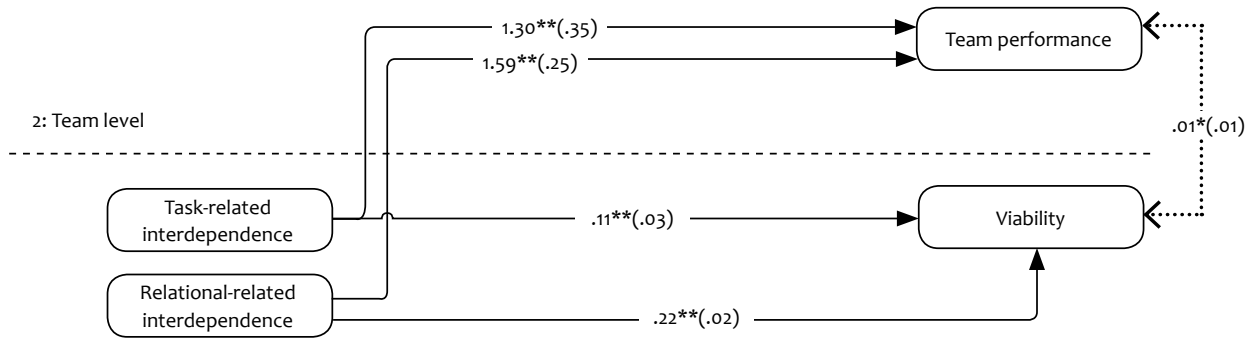

1: Individual level

Figure 2

Estimates of the relationship between perceived routines and team effectiveness (controlling for length of time together and team size)

Note. $\mathrm{RMSEA}=.05, \mathrm{R}_{\text {performance, taskrelational }}^{2}$ between $.02, \mathrm{R}^{2}$ viability, taskrelational = within .22 between .01 $* \mathrm{p}<.05,{ }^{* *} p<.01$

\section{Conclusion and discussion}

This study has tried to find empirical evidence for the presumed importance of routines for team effectiveness, by analysing its direct effect on team members' perceived team performance and members' individual-level viability. In order to test our cross-level model, a survey was undertaken in two VET colleges, where data were collected from 1624 team members of 289 teams. The results of the study show that, within the context of these two VET colleges, routines conceptualised as perceived interrelatedness (task- and relationalrelated interdependence) affect team effectiveness. Routines show a positive relationship with both the performance of the team and team members' viability. Moreover, the results show that task- and relational-related interdependence each had a different effect on team effectiveness. Relational-related interdependence seems to be more strongly associated with both the performance of a team and the team members' viability. This indicates that relationalrelated interdependence or "team members' expectations of what other members are going to do" affects the effectiveness of teams more than the perceived level of interdependence of tasks.

This empirical study shows how the concept of routines can advance our understanding of team effectiveness. Also, this study provides a conceptualisation for applying the concept of routines in empirical research. Furthermore, in today's organisations, where the work is primarily organised in teams, team effectiveness is becoming an important predictor of the success of organisations. Our findings provide insight into the factors which contribute 
to team effectiveness. In this case, they show that routines operationalised as perceived interrelatedness are of value for both the performance and members' ability to work well together. On the basis of these findings, we recommend that practitioners try to increase the level of routines within their team, by making team members task and relationally dependent on each other.

\section{Limitations and directions for future research}

It is important to note a few limitations to this study. Firstly, this study was conducted among team members of two VET colleges and therefore the conclusions are not immediately transferable to completely different settings. Before drawing the conclusion that routines are relevant to team effectiveness, it is necessary to test our model in other (including noneducational) contexts. Future studies in different contexts could strengthen the validity of the findings. Secondly, in this study only self-ratings of performance by team members were obtained. The next step could be to use both ratings from members and managers. Also, the research design can be expanded by adding more objective measures of team effectiveness. Finally, the last limitation to this study concerns its cross-sectional nature; we could not validate the causal nature of the relationships between the variables studies. Caution is therefore needed concerning the causal interpretation of the findings. Further research could use time-based designs to establish causal relationships. 


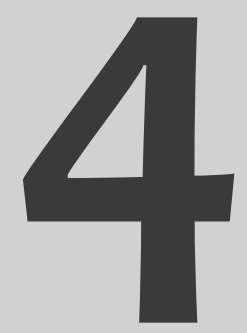

The mediating role of Group efficacy in the relationship between Routines and Team effectiveness 


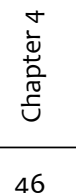


Because of rapid developments in technology, market and organisations, team-based working has become increasingly important in all kinds of organisations (e.g. De Dreu \& Weingart, 2003). Teams bring together people with different types of experience and knowledge, and thus teams are thought to be more capable of tackling complicated and continuously changing tasks than individuals working on their own (e.g. Sales, Goodwin, \& Burke, 2008; Van der Vegt \& Bunderson, 2005). Due to the increasing importance of teams in organisations, the number of studies on team effectiveness and conditions contributing to team effectiveness has increased over the past fifteen years (for overviews, see, Guzzo \& Dickson, 1996; Mathieu, Maynard, Rapp, \& Gilson, 2008; Stewart, 2006).

One of the factors that is expected to affect team effectiveness is group efficacy (Gully, Incalcaterra, Joshi, \& Beaubien, 2002). Group efficacy can be defined as "a group's collective estimate regarding the group's ability to perform a task objective" (Gibson, 2001, p. 790). Team members' positive beliefs about their capabilities are an important condition for teams to perform effectively. The relation between group efficacy and team effectiveness has been the subject of a large number of empirical studies, and in most studies a relation between these two has been found (Campion, Medsker, \& Higgs, 1993).

In addition to group efficacy, the concept of routines is increasingly associated with team effectiveness. Economic research especially suggests that routines are related to effectiveness and organisational performance (Becker, 2008). It is believed that routines standardise and structure the actions of team members; they are therefore important for optimising team functioning (Gersick \& Hackman, 1990). In contrast to group efficacy, the influence of routines on team effectiveness has often been suggested, but not yet supported by empirical evidence (Becker, 2005).

Besides the possible impact of routines on team effectiveness, routines may also influence group efficacy. According to Bandura (1997), past performance is an important factor in the development of group efficacy. In other words, a group's past successes and failures will have a strong effect on group efficacy for the particular task that the group is facing at any given moment. Routines capture the lessons learned from previous experience and enable a process to be replicated. Routines are therefore often used to codify best practices or collective capabilities (Gittell, 2002). It can thus be argued that routines may affect group efficacy, and that group efficacy will positively mediate the relationship between routines and team effectiveness. There is as yet no empirical support available for the role of group efficacy as one of the potential mechanisms that could explain why routines may foster team effectiveness. 
This study focuses on the relation between routines, group efficacy and team effectiveness. It is assumed that well-established routines lead to stronger beliefs among team members that they are able to perform effectively, which, in turn, influences team effectiveness (Champion, Medsker \& Higgs, 1993). The following research question guided our study: To what extent do routines affect team effectiveness, mediated by group efficacy?

In the next section, we use the existing research literature to define the different concepts in our study, and to discuss in greater depth how routines and group efficacy may be related to team effectiveness, and how group efficacy may mediate the relationship between routines and team effectiveness. Then, we present a model that hypothesises the relationships between the different variables. This model was tested using data from 450 members of 50 teams.

\section{Review of the Literature}

\section{Team Effectiveness}

One of the most comprehensive models that has guided research on team effectiveness for over forty years is the Input-Process-Outcome (IPO) model of McGrath (1964). In this model, inputs refer to resources available to the team from, for instance, individual team member characteristics (e.g. skills), processes refer to the activities of the team which transform the inputs into outputs, and outputs refer to the results and by-products of team activities. With respect to team outputs, researchers have used many different definitions to measure the results or by-products of team activities (see for a review Mathieu, Maynard, Rapp, \& Gilson, 2008). In the main, two indicators of team outputs were identified: team performance and the affective reactions of team members (Mathieu et al., 2008; ZellmerBruhn \& Gibson, 2006). Research on team effectiveness and routines has concentrated mainly on performance, rather than on affective reactions to study team outputs (Becker, 2005). Despite the preference for team performance as output measure, the definition of this construct has still been 'less systematically addressed' by researchers (Ilgen, 1999, p.131). The principal reason for this is that performance indicators are context specific. For instance, performance may refer to variables ranging from sales growth in a manufacturing organisation to the quality of social services provided in the field of social work. In order to deal with this problem, Hackman (1987) proposed defining team performance as the extent to which a team meets its objectives, and how well the output fulfils the team's mission. Following Hackman, many researchers have defined performance in relative terms, and used perceptions of team performance to measure team effectiveness, with responses taken as often from team members themselves as from team managers. In this study, we followed this line by measuring team effectiveness in terms of members' perceptions of the performance of their team. Apart from team performance, Hackman (1983) contends that a team that 
performs its task well, but is not able to work together in the future, is not an effective team. The stability of a team whose members are able to work well together and feel committed to the team is also an important indicator of effectiveness (viability). Following Hackman (1990), we include both output factors (performance and viability) in our study, to measure team effectiveness.

\section{Routines}

Routines can be defined as recurrent interaction patterns (Becker, 2005). Routines capture the way in which the tasks are typically accomplished by members of the team. In other words, routines indicate what is done by whom, thereby allowing members to form an expectation of each other's behaviour and take appropriate actions and interactions. Drawing on the seminal work of Nelson and Winter (1982), routines have been discussed and studied by many researchers from different disciplines (e.g., Becker, 2001; Cohen \& Bacdayan, 1994; Cohendet \& Lierena, 2003; Hodgson \& Knudsen, 2004; Lazaric, 2000; Pentland \& Feldman, 2008; Pentland \& Rueter, 1994). Although there is a continuous debate among these researchers about the nature and components of routines, there does seem to be agreement that the concept of routines has two dimensions: a behaviour dimension and a cognitive dimension (Pentland \& Feldman, 2008). The first dimension focuses on the recurrent behavioural patterns; routines are similar patterns of actions. Routines involve multiple employees, which indicates that routines refer not to individual patterns of action, but to actions involving multiple members (Becker, 2005). This dimension has been linked with routines since the beginning of research on routines (Becker, 2004). The problem with studying the behavioural dimension, however, is that we have to measure recurrent behavioural patterns, which implies a definition of what amounts to the 'same' behaviour (Becker, 2005). According to Winter (1990), this presents 'serious conceptual and measurement challenges' (p. 279), because members can influence behaviour that is repeated, rather than replicate it like a robot. The question is therefore whether identical repetition is possible at all (Becker, 2005; Nelson \& Winter, 1982). This is why the cognitive dimension seems to be the appropriate dimension for empirical research on routines. The cognitive dimension addresses the knowledge, enabling an employee to guide and refer to specific performances of a routine (Becker, 2008; Lazaric, 2000; Nelson \& Winter, 1982; Pentland \& Feldman, 2005). Although scholars support the idea that routines encode the knowledge of members, they employ different perspectives to conceptualise the construct of knowledge. As a result of this conceptual diversity, varying interpretations exist about the nature of routines as knowledge. For some scholars, the cognitive dimension refers to rules and standard operating procedures, which may produce recurrent behavioural patterns. There are several problems involved when reducing the cognitive dimension of routines to rules and standard operating procedures. For example, March (1997) argues that a rule itself does not determine individual choices and behaviour. He contends that 
the behaviour required by the rule may be shaped through interpretation (March, 1997, p.20). Feldman (2003) too argues that it would be incorrect to operationalise the cognitive dimension (in her study, the ostensive part of a routine) as a standard operating procedure, because it relates to the subjective understanding of members. Recently, researchers have defined the cognitive dimension of routines as dispositions to express the notion that routines are not behaviour; they are 'stored behavioural capabilities' (Hodgson, 2008; Hodgson \& Knudsen, 2004). Hodgson (2004) argues that the difference between understanding routines as behaviour patterns, or as cognition (in his study, defined as dispositions) is that, when triggered, the cognitive dimension is the causal mechanism that produces behaviour ( $p$. 653). In the view of Hodgson and Knudson (2004), it is necessary to include the causes of recurrent behavioural patterns in a study on routines. In line with recent approaches, this study focuses on the cognitive dimension of routines. To measure the cognitive dimension of routines, we need to assess the causes of recurrent behavioural patterns or, in other words, what exactly enables a team member to perform routines. Although every situation may be different and this may explain why most researchers define routines differently, what the definitions do have in common is that routines refer to interrelatedness (Dosi, Nelson \& Winter, 2000). Routines involve multiple employees. Routines are therefore phenomena that have to deal with a kind of interdependence. Interdependence refers to the degree to which the interaction and coordination of team members is necessary for the completion of tasks. Becker (2005) argues that interdependence is essential for the performance of recurrent behavioural patterns. To explore the relationship between routines and team effectiveness, we measure the extent of interrelatedness of team members. Interrelatedness is not a onedimensional concept; it consists of members' perceived level of task-related and relationalrelated interdependence. Task-related interdependence refers to the pattern in which team members have to exchange information and resources to accomplish their collective tasks in teams. Relational-related interdependence refers to members' expectations about how to work well together as a team. This division is also in line with team research in which researchers argue that, in order to be successful, team members must not only need to perform task-related functions but they must also work well together as a team (Mclntyre \& Sales, 1995). In this study, we expect that routines by measuring members' perceived interrelatedness, will be positively related to team effectiveness (Hypothesis 1).

\section{Group efficacy}

Group efficacy is regarded as a very important condition for team effectiveness (Champion, Medsker, \& Higgs, 1993; Gully, Joshi, Incalceterra, \& Beaubien, 2002; Zaccaro, Blair, Peterson, \& Zazanis, 1995). Group efficacy is based on the self-efficacy construct of Bandura (1982). Selfefficacy can be defined as a person's belief in his or her capabilities to perform a task, whereas group efficacy refers to group beliefs (Bandura, 1982; Lindsley, Brass, \& Thomas, 1995; Shea \& 
Guzzo, 1987). Group efficacy is not simply the sum of individual beliefs or their capabilities; it is "a shared belief in a collective's capabilities to organize and execute the courses of action" (Bandura, 1997, p. 477). As such, group efficacy perceptions are future-oriented beliefs about the functioning of a collective in a specific situation or context, and can lead to the cultivation of group beliefs in 'Yes, we can' (Mischel \& Nortcraft, 1997). Several empirical studies have shown a positive relationship between group efficacy and team effectiveness (e.g., Campion, Medsker, \& Higgs, 1993). For instance, Gully, et al. (2002) found in their meta-analysis of team effectiveness (including sixty-seven empirical studies) a meaningful positive relationship between groups that have confidence in their ability and team effectiveness (corrected mean correlation of .41).

Until now, research on group efficacy and team effectiveness has paid less attention to the factors that influence group efficacy (Pescosolido, 2001). Bandura (1997) argued that group efficacy is developed in a manner similar to personal self-efficacy. He distinguished four sources that contribute to the development of self-efficacy: past performance, vicarious experience, social persuasion, and psychological and affective states. According to Bandura, past performance (enactive mastery) is the most effective source for developing efficacy beliefs. Past successes will raise efficacy beliefs, while past failures will lower them. Routines capture the lessons learned from previous experience, enabling a process to be replicated. Routines are used to codify best practices or collective capabilities (Gittell, 2002). Thus, the function of routines is to allow team members to use standards and procedures, in order to structure and predict the behaviour of other team members and take appropriate actions and interactions. As a result, they know well what to do, and understand each other's behaviour. Based on Bandura's sources of efficacy, we expect that routines may be an important source of group efficacy. In this study, we test the assumption that routines enhance group efficacy (Bandura, 1997), and that these positive beliefs about the team, in turn, foster team effectiveness (Champion et al., 1993; Gully et al., 2002; Zaccaro et al., 1995) (Hypothesis 2).

\section{Method}

\section{Respondents}

The data collection for this study was conducted in a Vocational Education and Training (VET) college. The VET college consists of a number of educational departments, such as Technology, Economics and Business, Health and Welfare, and Education. These departments are further subdivided into teams, consisting primarily of teachers and teaching assistants. As a team, they are responsible for the coaching of a group of students, the guiding of these students' learning processes, curriculum planning, coordinating workplace learning and the assessment of these students. Within each team, team members must interact frequently, 
share information and coordinate, in order to perform these tasks. The data collection consisted of written questionnaires, distributed to 1184 team members. The questionnaires were mailed to team members' personal mailboxes in the period March - June 2010. After a reminder, the response from the 1184 team members was $38 \%(n=450$ in total 50 teams). The mean age of the respondents was 50 years, and $58 \%$ were women.

\section{Instruments}

In addition to some background information, the team members' questionnaire consisted of sets of items (scales) measuring the variables included in our model. The respondents could indicate to what extent the items referring to routines, group efficacy and team effectiveness applied to them on five-point Likert scales ( 1 = totally disagree, $5=$ totally agree).

As stated before, the dependent variable team effectiveness was measured by two separate scales: team performance and viability. Team performance was measured by asking team members about their performances as a team. We used the five-item scale of ZellmerBruhn and Gibson (2006). Examples of items are: "This team achieves its goals" and "This team serves the purpose it is intended to serve". We used the items from the "commitment to the group' scale of Ellmers, Kortekaas and Ouwerkerk (1999) to measure viability. The scale consisted of three items: "I would like to continue working with my group", "I dislike being a member of my group" and "I would rather belong to another group".

To study routines as cognition, we used two scales to assess members' perceived interrelatedness: task-related interdependence and relational-related interdependence. Taskrelated interdependence was measured using four items from the 'task interdependence scale' of Van der Vegt, Emans and Van de Vliert (1998), which refer to the pattern in which team members must exchange information and resources to complete their tasks in teams. An example item was: “To do my job, I need information from my colleagues".

In addition to this task-related interdependence, we also added a second scale, consisting of three statements, to measure members' expectations about how to work well together as team. As no scale for this dimension was available, we selected three items from the Work Scale (VBBA) of van Veldhoven and Meijman (1994), measuring ambiguities of work, and adjusted them, in order to assess relational-related interdependence. An example of an item from this scale is: "I know exactly what I can expect from my colleagues".

Finally, to measure group efficacy, two items of Goddard, Hoy and Woolfolk (2000) and two items of Schyns and Von Collani (2002) were included in the questionnaire. The scale of Schyns and Von Collani (2002) refers to the individual level concept of self-efficacy (Bandura, 1997). We therefore reformulated the items so that they referred to the team's group efficacy. An example is: "Whatever happens in our team, we can usually cope with it". 
We conducted a confirmatory factor analysis to guide scale construction. We used the following fit indices: the comparative fit index (CFI) and the Tucker-Lewis Index (TLI) (Tucker \& Lewis, 1973). The fit of the scale is considered acceptable when the CFI and TLI are above .90 (e.g. Bentler \& Bonnett, 1980). The findings show a good fit (CFI .92 and TLI .97), indicating that the items measure separate constructs. The Cronbach's alpha varied from 0.78 to 0.92 .

\section{Analysis}

Theory and recent research suggest that group efficacy and team performance are constructs at team level (Jung \& Sosik, 2003; Klein \& Kozlowski, 2000; Kozlowski \& Ilgen, 2006). However, the data were collected at the individual level. Therefore, the first step in the analysis was to find out if we could aggregate the data for these constructs at team level. We used the intraclass correlation (ICC) to test whether the individual perceptions of group efficacy and team performance could be aggregated to the team level. We calculated the ICC (1) and ICC (2). The ICC (1) indicates the extent of agreement between ratings from members of the same team, whereas the ICC (2) provides an estimate of the reliability of the group means. James (1982) reported a median ICC (1) of .12. For our team-level variables, the ICC (1) of group efficacy and team performance is .16 and .15 , indicating that a considerable part of the variance is between groups. For the ICC (2), a criterion of between .60 and .70 is sometimes used for aggregation. The ICC (2) is .57 for group efficacy and .56 for team performance. Since the ICC (2) value depends on team size, with higher values of ICC (2) as team size increases (Bliese, 2000), we chose to depend mainly on the outcomes of the ICC (1) and decided to aggregate the individual team members' ratings for these two indicators to the team level.

\section{Testing the model}

Figure 1 shows the mediating role of group efficacy in the relationship between routines and team effectiveness. As we have to deal with a variable affecting another variable at a higher level (upward effect) and a two-level design (employees are nested in teams), multilevel structural equation modelling (MSEM) in Mplus is the most suitable. The MSEM approach has recently been introduced by Preacher, Zyphur and Zhang (2010) for addressing 'upward' effects within multilevel data. Preacher et al. (2010) argued that other multilevel methods are limited, as they cannot accommodate a variable affecting another variable at a higher level. As a result, each effect in the causal chain entails a variable affecting another variable at the same or lower level (e.g., Krull \& MacKinnon, 2001). Thus, as Preacher et al. (2010) argued the 'upward' effects are ruled out using traditional multilevel modelling and they therefore proposed MSEM in Mplus, in order to overcome this limitation. Fit indices are necessary for the evaluation of multilevel structural equation modelling. The $\chi^{2}$-statistic is reported in virtually all reports involving structural equation modelling. If the corresponding $p$-value (given the degrees of freedom) exceeds a certain criterion (e.g. $p>.05$ ), the model can be 
accepted, but a serious problem with this statistic is its strong dependence on sample size. Another common type of fit index is expressed in terms of explained variance. That is, the researchers often seek to include predictors of a criterion such that the variance of residuals is reduced by some nontrivial amount. For example, the $\mathrm{R}^{2}$ in a regression framework equates effect size with the proportion of the total variance in one variable shared with, or explained by, one or more other variables. However, Preacher and Kelly (2011) argued that explainedvariance measures are not very informative for mediation models. Because there is no single (traditional) $\mathrm{R}^{2}$ in mediation analysis - even in single-level mediation - there are always at least two dependent variables in the model ( $M$ and $Y$ ). In our multilevel mediation model where some variables have variance at each level, it becomes even more complicated. Therefore, the fit of the MSEM model in the present study was assessed by means of alternative indices. Firstly, the comparative fit index (CFI) and the Tucker-Lewis index (TLI), which both assess the relative improvement in fit of the model tested in comparison with a model that assumes zero covariances among the observed variables. Scores for these indices that exceed .90 may be considered to indicate a reasonably good fit (Hox, 2002; Hu \& Bentler, 1999). Secondly, the root mean squared error of approximation (RMSEA) is a widely applied model fit index and is designed to assess how well the fitted model approximates the true model. With regard to this index, values below .08 are considered good (Hu \& Bentler, 1999). RMSEA values greater than .10 are considered to represent a poor fit.

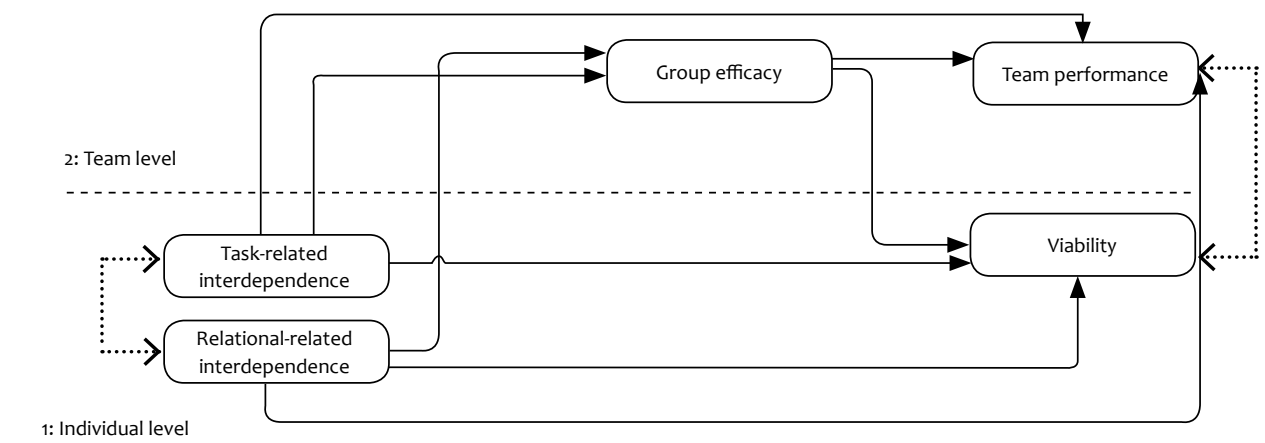

Figure 1

Upper effect in a two-level model 


\section{Results}

\section{Correlation analyses}

Means, standard deviations and correlations among the three predictor variables and the two outcome variables are shown in Table 1. As can be seen, team members' average ratings are high: in all cases above 3 on a five-point Likert scale. Viability shows the highest average $(M=4.32)$. As expected, significant positive correlations are found for relational-related interdependence (routines) and team effectiveness (team performance and viability), as well as group efficacy. However, the correlations also show that task-related interdependence (routines) do not correlate with team performance and viability.

\section{Table 1}

Means, Standard Deviations and Correlations

\begin{tabular}{|c|c|c|c|c|c|c|c|}
\hline Variables & $\begin{array}{c}\text { Mean } \\
\text { (scale 1-5) }\end{array}$ & s.d. & 1 & 2 & 3 & 4 & 5 \\
\hline 1.Team performance & 3.53 & .88 & & & & & \\
\hline 2. Viability & $4 \cdot 32$ & .84 & $.56 * *$ & & & & \\
\hline $\begin{array}{l}\text { 3. Routine: task-related inter- } \\
\text { dependence }\end{array}$ & 3.82 & .68 & -.06 & .05 & & & \\
\hline $\begin{array}{l}\text { 4. Routine: relational-related } \\
\text { interdependence }\end{array}$ & 3.49 & .91 & $.55^{* *}$ & $.39 * *$ & -.03 & & \\
\hline 5.Group efficacy & 3.57 & .76 & $.68 * *$ & $.55^{* *}$ & $.11^{*}$ & $.51 * *$ & \\
\hline
\end{tabular}

Note. $N=450$ To compute the individual-level Pearson correlations, the group's scores for group efficacy and team performance were assigned to each individual group member

$* p<.05, * * p<.01$

\section{Multilevel structural equation analyses}

The test of the multilevel structural equation model shows that our proposed model fits the data well: CFI and TLI were >.90 and RMSEA was <.08 (Hox, 2002; Hu \& Bentler, 1999). No relationships were found between the task-related interdependence (routines), team effectiveness (for both team performance and viability) and group efficacy (see Figure 2). Furthermore, the results show a significant positive relationship between relational-related interdependence (routines) and team effectiveness (team performance estimate $=1.03$, SE $=.31, p<.01$ and viability estimate $=.32, \mathrm{SE}=.04, p<.01$ ). This means that the more members know what can be expected of each other, the more they perceive their team to be effective. As such, this finding offers partial support for Hypothesis 1.

Regarding the relationships with group efficacy, the results show that relationalrelated interdependence (routines) had a positive effect on group efficacy (estimate $=1.23$, $S E=.22, p<.01)$. This result indicates that team members who displayed high relational 
interdependence, by indicating that they had knowledge of what other members were going to do, showed confidence in their collective capacity as a team.

Furthermore, the relationship between group efficacy and viability was found to be significant (estimate $=.64, \mathrm{SE}=.10, p<.01$ ).

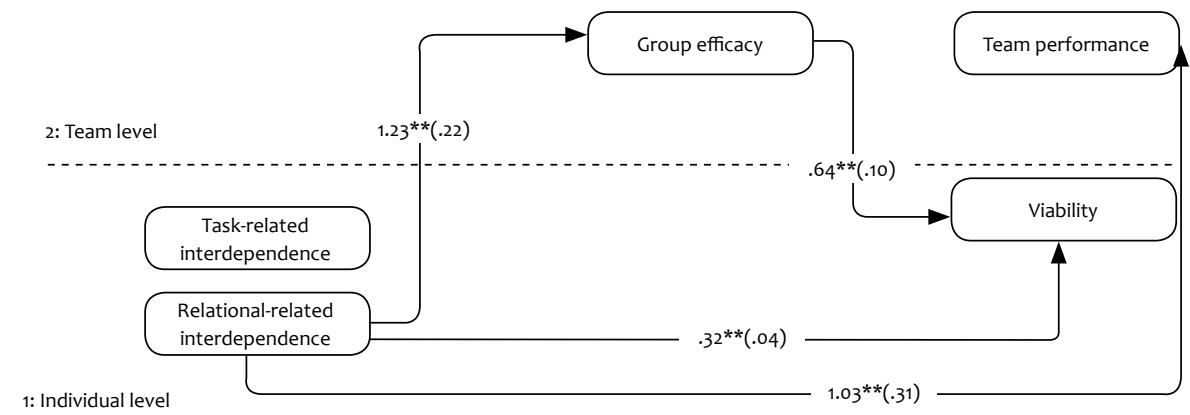

Figure 2

Estimates of the relationship between perceived routineness (task- and relational-related interdependence), group efficacy and team effectiveness

Note: $\mathrm{CFI}=.98 ; \mathrm{TLI}=.99 ; \mathrm{RMSEA}=.02$.

$* * p<.01$

Finally, the results indicate a significant indirect effect for relational-related interdependence via group efficacy on viability (estimate $=.79, \mathrm{SE}=.18, p<.01$ ). This finding suggests that the relationship between routines operationalised as relational-related interdependence and team effectiveness is mediated by group efficacy. This finding provides partial support for Hypothesis 2.

\section{Conclusion and discussion}

The present study focuses on two potential determinants of team effectiveness: routines and group efficacy. We tested a model to investigate the relationship between routines, group efficacy and team effectiveness. We used a cross-level model, which links two dimensions of routines - task-related interdependence and relational-related interdependence (individual level) - with group efficacy (team level) and team effectiveness (team performance and individual level viability). In order to test this model, data were used from a survey in a VET college of 450 members from 50 teams. 
The findings of this study support the premise that routines are related to team effectiveness. Routines conceptualized as perceived relational-related interdependence turns out to be a significant predictor of team effectiveness. It shows a positive relation with both the performance of the team and team members' viability (ability to work well together). Although we expected there to be a positive relationship between routines as perceived task-related interdependence and team effectiveness, we did not find a significant relationship between task-related interdependence as an indicator of routines and team effectiveness. These findings seem to reflect the fact that, as routine involve relational-related interdependence, such routines enable members to work together effectively.

With regard to the relationship between group efficacy and team effectiveness, the results show that group efficacy is related to team members' viability. These results are in line with other studies on group efficacy and team commitment (e.g., Pescosolido, 2003): it seems that members of teams with a strong shared belief in their collective capacity as a team are more committed to continuing as a group. Furthermore, the results show no significant relationship between group efficacy and team performance as perceived by the team members. This finding stands in contrast with findings from other studies, in which a strong link between group efficacy and team performance was found (e.g., Peterson, Mitchell, Thompson, \& Burr, 2000). It is remarkable therefore that we did not find a significant relationship between group efficacy and team performance. One possible explanation may be that in our study we measured team effectiveness by using self-ratings of performance by team members themselves. In future studies, researchers should use a multi-actor strategy, by asking experts, managers and team members to assess the performance of the teams. The results of these studies may contribute to a deeper understanding of the relationship between group efficacy and team performance.

Finally, the results show that group efficacy partially mediated the relationship between routines as relational-related interdependence and viability. This indicates that the more team members know what other members are going to do, the more they have positive shared beliefs about their collective capacity, which will, in turn, foster their ability to work well together. This stresses the need for the management of relational interdependence in teams. Furthermore, the results reveal neither an indirect relationship for task-related interdependence (routines) via group efficacy on team performance, nor an indirect relationship for task-related interdependence via group efficacy on team members' viability. Thus, the results of this study suggest that the effect of routines might be due mainly to the role of relational-related interdependence in stimulating team effectiveness (viability) via group efficacy. 


\section{Limitations and directions for future research}

Despite the potential of this study, some limitations need to be mentioned. The first limitation concerns the design used. More studies examining the causal nature of the relationship between the variables would help to validate the causal direction between the variables. The causal ordering of routines and group efficacy may be just the opposite of what has been put forward. For example, teams who believe in their efficacy will be more motivated to do the things it takes to develop relational interdependence. Future studies could use timebased designs to establish causal relations. In addition, the sample of this study, consisting of teachers, is likely to be restricted to a certain group with similar characteristics. It is not yet known whether similar results would be found in other types of organisations. More research in different organisational settings is recommended. Another limitation to our study is that the sample size at team level is limited. It should, however, be noted that, to date, no research has investigated the question of appropriate sample size for the MSEM model (Preacher et al., 2010). Finally, we relied on self-reports to gather our data. A problem associated with selfreports is common method variance (Spector, 2006). In order to avoid potential common method variance, future studies could use, for instance, multiple types of respondents (e.g. team managers) and multiple methods (e.g. case studies). 


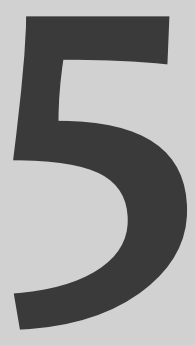

Effects of Transformational leadership and Routines on Group efficacy and Team effectiveness. ${ }^{1}$ A comprehensive model

${ }^{1}$ This chapter is a modified version of the manuscript Truijen, K.J.P., Sleegers, P.J.C., Meelissen, M.R.M., \& Nieuwenhuis, A.F.M. (submitted). Factors that influence effective team functioning in a vocational education context. 


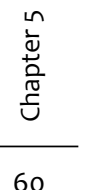


During the past decade, work teams have received a lot of attention from researchers, who have studied their relationship to various organisational outcomes (De Dreu \& Weingart, 2003; Guzzo \& Shea, 1992; Hackman, 1990; Sales, Goodwin, \& Burke, 2008). It is assumed that teams with shared responsibilities are better equipped to deal with complex tasks and fast changes than individual employees. In the research on team effectiveness the main focus is on what are known as 'emergent states': variables that characterise "properties of the team that are typically dynamic in nature and vary as a function of team context, inputs, processes and outcomes" (Marks, Mathieu, \& Zaccaro, 2001, p. 357). One of these 'emergent states', variables that have been found to be positively related to team effectiveness, is group efficacy (Champion, Medsker, \& Higgs, 1993). Group efficacy can be defined as "a group's collective estimate regarding the group's ability to perform a task objective” (Gibson, 2001, p.790). Given that group efficacy motivates members to perform better as a team, the question then is how group efficacy develops, and thus, what are the potential antecedents that may enhance group efficacy and, in turn, affect team effectiveness.

Two variables that have recently received much theoretical attention as potential antecedents are transformational leadership (e.g., Dionne, Yammarino, Atwater, \& Spangler, 2004; Lim \& Ployhart, 2004), and routines (e.g., Becker, 2008). There is reason to believe that transformational leaders can influence group efficacy. For example, Bass and Avolio (1994) suggested that transformational leaders have the ability to enhance followers' collective motivation and confidence, by elevating the salience of the group and its capabilities, while also supporting followers in achieving their collective goals. Besides the possible impact of transformational leadership on group efficacy, transformational leadership may influence team effectiveness as well. Whereas the relationship with effectiveness is a major theme in research on transformational leadership (e.g., Bass, 1985), empirical studies examining the relationship between transformational leadership and team effectiveness are scarce (Judge \& Piccolo, 2004; Schaubroeck, Lam, \& Cha, 2007).

In addition to leadership, scholars have emphasised the importance of routines for organisational effectiveness (Becker, 2008). The discussion about the role routines have in enhancing work group processes and team effectiveness focuses on how routines could facilitate coordinated action by stable behaviour patterns (Becker, 2005; Gittell, 2002; March, 1991). Stable behaviour patterns enable members to form expectations and make appropriate decisions about interactions, leading to greater coordination. Well-coordinated work processes are expected to produce enhanced performance. With the increasing attention from researchers on teamwork, the question of how these routines work at the inter-individual level has become an important issue (Edmondson, Bohmer, \& Pisano, 2001). However, empirical studies on the relationship between routines, group efficacy and team effectiveness are still relatively rare. 
This study provides a contribution to the knowledge base of work teams, by examining the relation between transformational leadership and routines on the one hand, and group efficacy and team effectiveness on the other. We expect that transformational leadership and routines will enhance group efficacy in the team, and that positive beliefs about capabilities in a team will foster team effectiveness. The main question addressed in this study is: To what extent do transformational leadership and routines affect team effectiveness, as mediated by group efficacy?

We first provide a review of the relevant literature and discuss how transformational leadership and routines may be related to team effectiveness, and how group efficacy mediates the relationship. After reviewing the literature, we present a model that hypothesises the relationships between the different variables. This model was tested using data from 450 members of 50 teams.

\section{Review of the literature}

\section{Team Effectiveness}

Although researchers have employed many different indicators to study team effectiveness (for a review, see Mathieu, Maynard, Rapp, \& Gilson, 2008), two indicators of team effectiveness are frequently identified: team performance (i.e., quality and quantity of team outputs) and the affective reactions of team members (Mathieu et al., 2008; ZellmerBruhn \& Gibson, 2006). Research on team effectiveness and routines has focused mostly on performance, rather than on affective reactions to study team outputs (Becker, 2005). In spite of the preference for team performance as output measure, the definition of this construct has still been 'less systematically addressed' by researchers (Ilgen, 1999, p.131). The principal reason for this is that performance indicators are context specific. For instance, performance may refer to variables ranging from sales growth in a manufacturing organisation to the quality of social services provided in the domain of social work. In order to deal with this problem, Hackman (1987) proposed defining team performance as the degree to which a team attains its goals, and how well the output accomplishes the team's mission. Following Hackman, many researchers have defined performance in relative terms, and applied perceptions of team performance to measure team effectiveness, with responses gathered from team members themselves as often as from team managers. In this study, we pursued this approach, by measuring team effectiveness as members' perceptions of the performance of their team. Besides team performance, Hackman (1983) argues that a team that performs its task well, but is not able to work together in the future, is not an effective team. The stability of a team whose members are able to work well together and feel committed to the team is also a significant indicator of effectiveness (viability). Following Hackman (1990), 
we include both output factors (performance and viability) in our study, in order to measure team effectiveness.

\section{Transformational leadership}

Leadership is widely regarded as playing a significant role in organisational change and effectiveness, especially as it is inspired by the concept of transformational leadership. This concept of leadership, as developed by Burns (1978), fundamentally aims to foster capacity development and higher levels of personal commitment to organisational goals on the part of the followers, resulting in extra effort and greater productivity (Bass, 1985; Bass, \& Avolio, 1994; Burns, 1978). Following the work of Burns (1978), Bass (1985) developed a model of transformational leadership that conceptualised transactional and transformational leadership forms as separate but interdependent dimensions. Transactional leadership behaviours are those that are associated with 'transactions' between leaders and followers, and are often associated with the clarification of goals and objectives and providing recognition once goals have been achieved. Transformational leadership involves a leader's ability to increase organisational members' commitment, capacity and engagement in meeting goals. Transformational behaviours are those that motivate followers to perform beyond standard expectations for performance. Whereas transactional leadership seeks to satisfy followers' individual needs as a reward for completing a given transaction, transformational leadership motivates followers to go beyond their own self-interest for the sake of the group. In other words, transformational leaders help followers to become highly committed to a common vision, and change followers' motivation from self-interest to collective interest (Avolio, Jung, Murry, \& Sivasubramaniam, 1996; House \& Shamir, 1993; Jung \& Sosik, 2002;). Scholars who have investigated transformational leadership have distinguished four dimensions: idealised influence (charismatic role modelling), inspirational motivation (articulating an appealing and/or evocative vision), intellectual stimulation (promoting creativity and innovation) and individualised consideration (coaching and mentoring) (Avolio, Bass, \& Jung, 1999).

Although many studies have examined the relationship between transformational leadership and effectiveness at the individual and organisational level of analysis (e.g., Lowe, Kroeck, \& Sivasubramaniam, 1996; Patterson, Fuller, Kester, \& Stringer, 1995), relatively few studies have examined the impact of transformational leadership on team effectiveness. For example, meta-analyses show a positive relation between transformational leadership and organisational performance, for different organisational contexts and different performance criteria (e.g., organisational innovation: Howell \& Higgens, 1990; Shin \& Zhou, 2003). With the growing importance of teamwork in organisations, more fine-grained knowledge is needed of the relation between transformational leadership and team effectiveness (Dionne, Yammarino, Atwater, \& Spangler, 2004; Schaubroeck, Lam, \& Cha, 2007). Recently, 
some researchers have started to explore the link between transformational leadership and team effectiveness (Bass, Avolio, Jung, \& Berson, 2003; Jung \& Sosik, 2002; Lim \& Ployhart, 2004; Schaubroeck, et al., 2007). For example, in a study of forty-seven groups from four Korean firms, Jung and Sosik (2002) found that transformational leadership was positively related to group effectiveness. Specifically, transformational leadership can increase team effectiveness by motivating followers to cooperate in performing collective tasks, and providing the opportunity to learn from shared experience (Bass, 1985). In this study, we expect transformational leadership to be positively related to team effectiveness (Hypothesis 1).

\section{Routines}

Routines can be defined as recurrent interaction patterns (Becker, 2005). Routines encapsulate the way in which the tasks are typically accomplished by members of the team. In other words, routines indicate what is done by whom, thus allowing members to shape an expectation of each other's behaviour and take appropriate actions and interactions. Drawing on the seminal work of Nelson and Winter (1982), routines have been discussed and studied by numerous researchers from different disciplines (e.g. Becker, 2001; Cohen \& Bacdayan, 1994; Cohendet \& Lierena, 2003; Hodgson \& Knudsen, 2004; Lazaric, 2000; Pentland \& Feldman, 2008; Pentland \& Rueter, 1994). While the debate continues among these researchers about the nature and components of routines, there would seem to be a consensus that the concept of routines has two dimensions: a behaviour dimension and a cognitive dimension (Pentland \& Feldman, 2008). The first dimension addresses recurrent behavioural patterns; routines are similar patterns of actions. Routines involve multiple employees, which indicates that routines refer not to individual patterns of actions, but to actions involving multiple members (Becker, 2005). This dimension has been linked with routines since the research on routines started (Becker, 2004). However, the problem with studying the behavioural dimension is that we have to measure recurrent behavioural patterns, which implies a definition of what constitutes the 'same' behaviour (Becker, 2005). Winter (1990) argues that this poses 'serious conceptual and measurement challenges' ( $p$. 279), because members can influence behaviour that is repeated, rather than replicate it like a robot. Consequently, the question is whether identical repetition is possible at all (Becker, 2005; Nelson \& Winter, 1982). This explains why the cognitive dimension seems to be the appropriate dimension for empirical research on routines. The cognitive dimension addresses the knowledge that enables an employee to guide and refer to specific performances of a routine (Becker, 2008; Lazaric, 2000; Nelson \& Winter, 1982; Pentland \& Feldman, 2005). Scholars support the notion that routines encode the knowledge of members, although they use different perspectives to conceptualise the construct of knowledge. As a consequence of this conceptual diversity, varying interpretations exist as to the nature of routines as knowledge. For some scholars, 
the cognitive dimension refers to rules and standard operating procedures that can lead to recurrent behavioural patterns. There are several problems when reducing the cognitive dimension of routines to rules and standard operating procedures. For example, March (1997) argues that a rule does not in itself determine individual choices and behaviour. He argues that the behaviour required by the rule may be shaped through interpretation (March, 1997, p.20). Feldman (2003) also argues that it would be a mistake to operationalise the cognitive dimension (in her study, the ostensive part of a routine) as a standard operating procedure, since it is about the subjective understanding of members. Recently, researchers have defined the cognitive dimension of routines as dispositions to express the idea that routines are not behaviour; they are 'stored behavioural capabilities' (Hodgson, 2008; Hodgson \& Knudsen, 2004). Hodgson (2004) contends that the difference between understanding routines as behaviour patterns, or as cognition (in his study defined as dispositions), is that, when triggered, the cognitive dimension is the causal mechanism that produces behaviour (p. 653). According to Hodgson and Knudson (2004), it is necessary to include the causes of recurrent behavioural patterns in a study on routines. In line with recent approaches, this study focuses on the cognitive dimension of routines. To measure the cognitive dimension of routines, it is necessary to assess the causes of recurrent behavioural patterns or, in other words, what it is precisely that enables a team member to perform routines. Although every situation might be different, and this might explain why most researchers define routines in a different way, what the definitions do share is the belief that routines refer to interrelatedness (Dosi, Nelson \& Winter, 2000). Routines involve multiple employees. Routines are therefore phenomena that have to deal with a kind of interdependence. Interdependence refers to the degree to which the interaction and coordination of team members is necessary to complete tasks. Becker (2005) claims that interdependence is crucial to the performance of recurrent behavioural patterns. To explore the relationship between routines and team effectiveness, we measure the extent of interrelatedness of team members. Interrelatedness is not a onedimensional concept; it consists of members' perceived level of task-related and relationalrelated interdependence. Task-related interdependence refers to the pattern in which team members have to exchange information and resources to accomplish their collective tasks in teams. Relational-related interdependence refers to members' expectations of how to work well together as a team. This division is also in line with team research in which researchers argue that, in order to ensure success, team members must not only need to perform taskrelated functions, but also work well together as a team (McIntyre \& Sales, 1995). In this study, we expect that routines by measuring members' perceived interrelatedness, will be positively related to team effectiveness (Hypothesis 2). 


\section{Group efficacy}

Scholars in leadership and organisational behaviour often assume that group efficacy is the factor that explains why transformational leadership and routines may be related to work group effectiveness and organisational performance (e.g. Truijen, et al., in progress; Walumbwa, Wang, Lawler \& Shi, 2004). Group efficacy is based on the self-efficacy construct of Bandura (1982). Self-efficacy can be defined as a person's belief in his or her capabilities to perform a task, whereas group efficacy refers to group beliefs (Bandura, 1982; Lindsley, Brass, \& Thomas, 1995; Shea \& Guzzo, 1987). Group efficacy is not simply the sum of individual beliefs or their capabilities, it is "a shared belief in a collective's capabilities to organise and execute the courses of action" (Bandura, 1997, p. 477). As such, group efficacy perceptions are future-oriented beliefs about the functioning of a collective in a specific situation or context, and can lead to the cultivation of group beliefs in 'Yes, we can' (Mischel \& Nortcraft, 1997). Several empirical studies have shown a positive relationship between group efficacy and team effectiveness (Campion, Medsker, \& Higgs, 1993). For instance, Gully, Joshi, Incalceterra and Beaubien (2002) found in their meta-analysis of team effectiveness (including sixty-seven empirical studies) a meaningful positive relationship between groups that have confidence in their ability and team effectiveness (corrected mean correlation of .41).

Bandura (1997) argued that group efficacy is developed in a manner similar to self-efficacy at the individual level. Bandura recognised four sources of self-efficacy: past performance, vicarious experience, social persuasion, and psychological and affective states. Firstly, past performance and failures will have a strong effect on efficacy. Past successes will raise efficacy beliefs, while past failures will lower them. Secondly, vicarious experience is achieved through the modelling of successful performance by someone who is similar to the individual. Thirdly, verbal persuasion is having other people consistently express the belief that one is capable of performing in the required manner. Finally, psychological and emotional arousal can also affect efficacy beliefs. For example, a positive mood can enhance efficacy beliefs, while a negative mood may diminish them. Scholars have argued that transformational leadership influences group efficacy, especially through role modelling (vicarious experience) and verbal persuasion (Podsakoff, Mackenzie, Moorman, \& Fetter, 1990; Schaubroeck, Lam, \& Cha, 2007). For example, Schaubroeck, Lam and Cha (2007) suggested that transformational leaders influence followers by role modelling the appropriate behaviour and encouraging followers to engage in such behaviour. Moreover, Bass and Avolio (1994) suggested that transformational leaders have the ability to enhance followers' collective motivation and confidence, by elevating the salience of the group and its capabilities, while also supporting followers in achieving their collective goals. Furthermore, on the basis of Bandura's sources, we argue that routines could also be an important source of group efficacy. As mentioned earlier, past performance (enactive mastery) is an important source for developing efficacy 
beliefs. Routines capture the lessons learned from previous experience, enabling a process to be replicated. Routines are used to codify best practices or collective capabilities (Gittell, 2002). Thus, the function of routines is to allow team members' structure and normative standards to predict and explain the behaviour of other team members and take appropriate actions and interactions. As a result, they know well what to do, and understand each other's behaviour (Nelson \& Winter, 1982).

Thus, in this study, we expect that transformational leadership and routines will enhance group efficacy (e.g., Bandura, 1997), and that these positive beliefs about the team will, in turn, foster team effectiveness (Lindsley, Brass, \& Thomas, 1995; Shea \& Guzzo, 1987) (Hypothesis 3). Although evidence concerning this expectation is thin on the ground, some research has suggested that the relationship between transformational leadership, routines and team work may be mediated by group efficacy. In a study of 402 employees from the banking and finance sectors in China and India, Walumbwa, Wang, Lawler and Shi (2004) had already found that transformational leadership affected group efficacy (i.e. collective efficacy) and that group efficacy, in turn, affected work outcomes. In a previous study, we found that group efficacy partially mediated the relational-related interdependence (routines) - team effectiveness relationship (Truijen, et al., in progress).

\section{Method}

\section{Respondents}

The data collection for this study was conducted in a Vocational Education and Training (VET) college. The VET college consists of a number of educational departments, such as Technology, Economics and Business, Health and Welfare, and Education. These departments are further subdivided into teams, consisting primarily of teachers and teaching assistants. As a team, they are responsible for the coaching of a group of students, the guiding of these students' learning processes, curriculum planning, coordinating workplace learning and the assessment of these students. Within each team, team members must interact frequently, share information and coordinate, in order to perform these tasks. The data collection consisted of written questionnaires, distributed to 1184 team members. The questionnaires were mailed to team members' personal mailboxes in the period March - June 2010. After a reminder, the response from the 1184 team members was $38 \%(n=450$ in total 50 teams). The mean age of the respondents was 50 years, and $58 \%$ were women

\section{Instruments}

In addition to some background information, the team members' questionnaire consisted of sets of items (scales) measuring variables in our model All respondents were asked to 
indicate to what extent the item content applied to them on a five-point Likert scale ( $1=$ totally disagree, 5 = totally agree).

As stated before, the dependent variable team effectiveness was measured by two separate scales: team performance and viability. Team performance was measured by asking team members about their performances as a team. We used the five-item scale of ZellmerBruhn and Gibson (2006). Examples of items are: "This team achieves its goals" and "This team serves the purpose it is intended to serve". The Cronbach's alpha for this scale was 92.

We used the items from the 'commitment to the group' scale of Ellmers, Kortekaas and Ouwerkerk (1999) to measure viability. The scale consisted of three items: "I would like to continue working with my group", "I dislike being a member of my group" and "I would rather belong to another group". The Cronbach's alpha for this scale was .82.

Transformational leadership was measured using the 'charisma items' of the CLIO ('Questionnaire for Charismatic Leadership in Organizations'), which was developed by de Hoogh, den Hartog and Koopman (2004). The scale consists of sixteen items. The following are examples of items from this scale: "My supervisor talks to employees about what is important to them" and "My supervisor is always looking for new opportunities for the organization". The Cronbach's alpha for this scale was .97.

To study routines as cognition, we used two scales to assess members' perceived interrelatedness: task-related interdependence and relational-related interdependence. Taskrelated interdependence was measured using four items from the 'task interdependence scale' of Van der Vegt, Emans and Van de Vliert (1998), which refer to the pattern in which team members have to exchange information and resources to complete their tasks in teams. An example item was: "To do my job, I need information from my colleagues". The Cronbach's alpha for this scale was .78.

Besides this task-related interdependence, we also added a second scale, consisting of three statements to measure members' expectations about how to work well together as a team. As no scale for this dimension was available, we selected three items from the Work Scale (VBBA) of van Veldhoven and Meijman (1994), measuring ambiguities of work, and adjusted them, in order to assess relational-related interdependence. An example of an item from this scale is: "I know exactly what I can expect from my colleagues". The Cronbach's alpha for this scale was also sufficient $(\alpha=.89)$.

Finally, to measure group efficacy, two items of Goddard, Hoy and Woolfolk (2000) and two items of Schyns and Von Collani (2002) were included in the questionnaire. The scale of Schyns and Von Collani (2002) refers to the individual level concept of self-efficacy (Bandura, 1997). We therefore reformulated the items so that they referred to group efficacy. An example is: "Whatever happens in our team, we can usually cope with it". Despite the combination of the two scales and the reformulation, the scale turned out to be of high reliability $(\alpha=.83)$. 


\section{Analysis}

Theory and recent research suggest that team performance and group efficacy are constructs at team level (Jung \& Sosik, 2003; Klein \& Kozlowski, 2000; Kozlowski \& Ilgen, 2006). Moreover, many leadership researchers also suggest that team members are likely to be consistent (homogeneous) in their perceptions of the leader. For example, interaction between team members is likely to render team members homogeneous in their perceptions of the leader (Yammarino \& Dansereau, 2009). In addition to team performance and group efficacy, in this study we also suggest that transformational leadership is a construct at team level. However, the data of transformational leadership, team performance and group efficacy were collected at the individual level. The first step in the analysis was therefore to find out if we could aggregate the data for these constructs at team level. We used the intraclass correlation (ICC) to test whether transformational leadership, team performance and group efficacy could be aggregated to team level. We calculated the ICC (1) and ICC (2). The ICC (1) indicates the extent of agreement between ratings from members of the same team, whereas the ICC (2) provides an estimate of the reliability of the group means. James (1982) reported a median ICC (1) of .12. For our team-level variables, the ICC (1) of transformational leadership, team performance and group efficacy was $.18, .15$ and .16 , indicating that a considerable part of the variance is between groups. For the ICC (2), a criterion of between .60 and .70 is sometimes used for aggregation. The ICC (2) is .64 for transformational leadership, .56 for team performance, and .57 for group efficacy. Since the ICC (2) value depends on team size, with higher values of the ICC (2) as team size increases (Bliese, 2000), we chose to depend mainly on the outcomes of the ICC (1) and decided to aggregate the individual team members' ratings for these three indicators to team level.

\section{Testing the model}

Figure 1 represents our conceptual model. The figure shows the mediating role of group efficacy in the relationship between transformational leadership, routines and team effectiveness. Since we have to deal with a variable affecting another variable at a higher level (upward effect) and two nested levels (employees are nested in teams), multilevel structural equation modelling (MSEM) in Mplus is the most appropriate. The MSEM approach has recently been introduced by Preacher, Zyphur and Zhang (2010) for addressing 'upward' effects within multilevel data. Preacher et al. (2010) argued that other multilevel methods are limited, because they cannot accommodate a variable affecting another variable at a higher level and, as a result, each effect in the causal chain involves a variable affecting another variable at the same or lower level (e.g., Krull \& MacKinnon, 2001). Thus, as Preacher et al. (2010) argued, the 'upward' effects are ruled out using traditional multilevel modelling and they therefore proposed MSEM in Mplus, in order to overcome this limitation. Fit indices are necessary for the evaluation of multilevel structural equation modelling. The $\chi^{2}$-statistic is 
reported in virtually all reports involving structural equation modelling. If the corresponding p-value (given the degrees of freedom) exceeds a certain criterion (e.g. p > .05), the model can be accepted, but a serious problem with this statistic is its strong dependence on sample size. Another common type of fit index is expressed in terms of explained variance. That is, the researchers often seek to include predictors of a criterion such that the variance of residuals is reduced by some nontrivial amount. For example, the $\mathrm{R}^{2}$ in a regression framework equates effect size with the proportion of the total variance in one variable shared with, or explained by, one or more other variables. However, Preacher and Kelly (2011) argued that explainedvariance measures are not very informative for mediation models. Because there is no single (traditional) $\mathrm{R}^{2}$ in mediation analysis - even in single-level mediation - there are always at least two dependent variables in the model ( $M$ and $Y$ ). In our multilevel mediation model where some variables have variance at each level, it becomes even more complicated. Therefore, the fit of the MSEM model in the present study was assessed by means of alternative indices. The fit of the MSEM model was assessed by means of the comparative fit index (CFI) and the Tucker-Lewis index (TLI), which both assess the relative improvement in fit of the model tested, in comparison with a model that assumes zero covariances among the observed variables. Scores of these indices that exceed .90 may be considered to indicate a reasonably good fit (Hox, 2002; Hu \& Bentler, 1999).

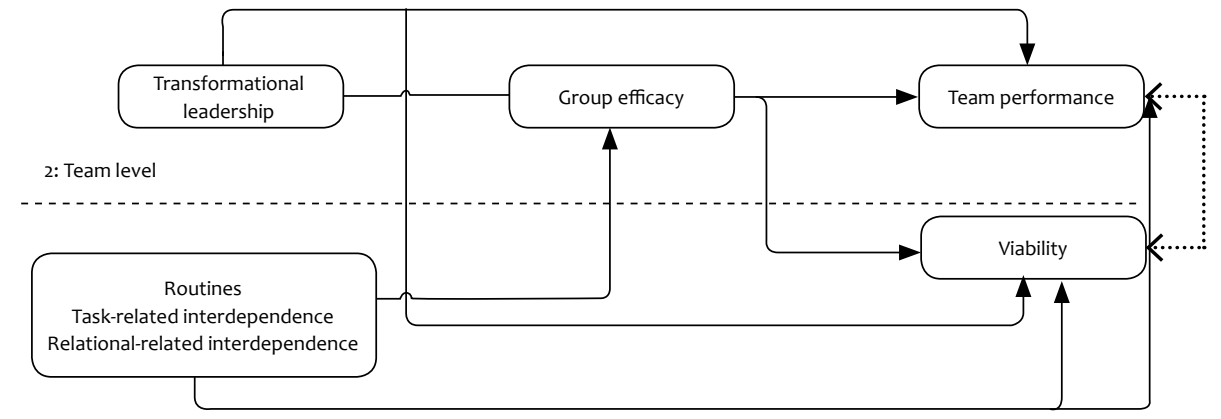

1: Individual level

Figure 1

Upper effects in a two-level model

\section{Results}

\section{Correlation analyses}

Means, standard deviations and correlations among the four predictor variables and the two outcome variables are shown in Table 1. As can be seen, team members' average ratings were high (above 3 on a five-point Likert scale). Viability showed the highest average $(M=4.32)$. 
Table 1

Means, Standard Deviations, and Correlations

\begin{tabular}{lcccccccc}
\multicolumn{1}{c}{ Variables } & $\begin{array}{c}\text { Mean } \\
\text { (scale 1-5) }\end{array}$ & s.d. & 1 & 2 & 3 & 4 & 5 & 6 \\
$\begin{array}{l}\text { 1. Team performance } \\
\text { 2. Viability }\end{array}$ & 3.53 & .88 & & & & & \\
$\begin{array}{l}\text { 3. Transformational leader- } \\
\text { ship }\end{array}$ & 3.32 & .84 & $.33^{* *}$ & & & & \\
$\begin{array}{l}\text { 4. Routine: task-related } \\
\text { interdependence }\end{array}$ & 3.82 & .68 & -.02 & .05 & .06 & & \\
$\begin{array}{l}\text { 5. Routine: relational-related } \\
\text { interdependence }\end{array}$ & 3.49 & .91 & $.32^{* *}$ & $.21^{* *}$ & $.39^{* *}$ & $.16^{* *}$ & -.03 & \\
\begin{tabular}{l} 
6. Croup efficacy \\
\hline
\end{tabular} & 3.57 & .76 & $.87^{* *}$ & $.30^{* *}$ & $.39^{* *}$ & -.02 & $.28^{* *}$ \\
\hline
\end{tabular}

Note. $\mathrm{N}=450$ To compute the individual-level Pearson correlations, the group's scores for transformational leadership, group efficacy and team performance were assigned to each individual group member $* \mathrm{p}<.05,{ }^{* *} \mathrm{p}<.01$

\section{Multilevel structural equation analyses}

The present study uses multilevel structural equation modelling (MSEM). Like other studies of SEM, MSEM has two primary goals. The first is to assess how good the fit of the model to the data is, and the second is to identify and test the effects of transformational leadership, routines and group efficacy on team effectiveness (see Figure 2). Although the fit of this model is acceptable for the CFI indicator: $\mathrm{CFI}>.90$, the TLI indicator shows that this model is not probable: TLI < .90 (see Figure 2) (Hox, 2002; Hu \& Bentler, 1999). However, inspection of the fit indices (Ryu \& West, 2009) showed that the approach to evaluating the model fit in MSEM is limited. According to Ryu and West (2009), if the approach indicates a poor fitting model, it is unknown whether the poor fit occurred in the between-group, within-group or both models. Since hardly any research has investigated the question of appropriate fit indices for the MSEM model, we chose to depend mainly on the outcomes of the CFI indicator which indicated an acceptable fit of the path model applied to the data.

The results show a significant positive relationship between transformational leadership and team effectiveness (team performance estimate $=.23, \mathrm{SE}=.10, p<.05$ and viability estimate $=.23, S E=.10, p<.05$ ). More specifically, our results suggest the importance of leaders who use more transformational behaviour: it seems to enhance team performance and team members' viability (ability to work together). These findings provide support for Hypothesis 1. We also found a significant positive relationship between relational-related interdependence (routines) and team effectiveness (team performance estimate $=.96, \mathrm{SE}=$ $.27, p<.01$ and viability estimate $=.32, \mathrm{SE}=.05, p<.01)$. This means that the greater the team members' knowledge is of what other members are going to do, the more effective the team members perceive their team to be. The results show no significant relationship between 
task-related interdependence (routines) and team effectiveness. As such, this finding offers partial support for Hypothesis 2.

Regarding the relationships with group efficacy, the results show that transformational leadership had no significant effect on group efficacy. There is a significant positive relationship between relational-related interdependence (routines) and group efficacy (estimate $=1.11^{* *}, \mathrm{SE}=.05, p<.01$ ). This result indicates that team members who displayed high relational-related interdependence, by indicating that they had knowledge of what other members were going to do, showed confidence in their collective capacity as a team. Furthermore, the relationship between group efficacy and viability was found to be significant (estimate $=.52, \mathrm{SE}=.11, p<.01$ ).

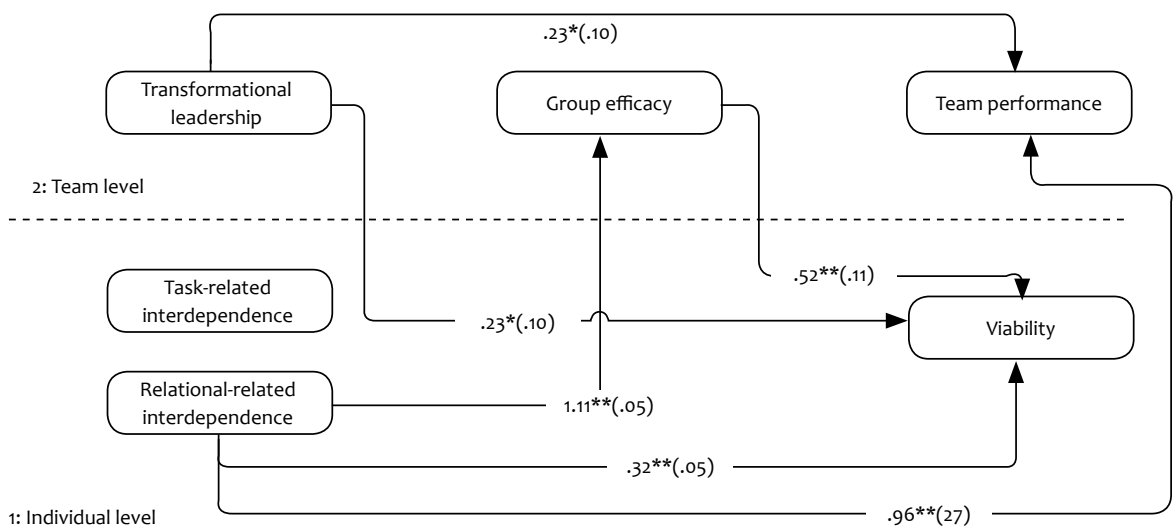

\section{Figure 2}

Estimates of the relationship between transformational leadership, routines, group efficacy and team effectiveness

Notes. $\mathrm{CFI}=0.97 ; \mathrm{TLI}=0.86$

$* * p<.01 ; * p<.05$

In addition, the analysis also shows a significant indirect effect for relational-related interdependence via group efficacy on viability (estimate $=.57, \mathrm{SE}=.15, p<.01$ ). Furthermore, it was hypothesised that group efficacy should partially mediate the relationship between transformational leadership and team effectiveness. This effect was not found. The results therefore provide partial support for Hypothesis 3. 


\section{Conclusion and discussion}

The present study focuses on three potential determinants of team effectiveness: transformational leadership, routines and group efficacy. We tested a model to investigate the relationship between transformational leadership, routines, group efficacy and team effectiveness. We used a cross-level model, which links transformational leadership (team level) and two dimensions of routines (individual level) - with group efficacy (team level) and team effectiveness (team performance and individual level viability). In order to test this model, data were used from a survey in a VET college of 450 team members from 50 teams.

The findings of this study support the premise that transformational leadership is positively related to team effectiveness. More specifically, these results suggest the importance of leaders who use more transformational behaviour: this seems to enhance team performance and team members' viability (ability to work together). These results add to similar findings that indicate that transformational leadership is related to team effectiveness (Bass, Avolio, Jung, \& Berson, 2003; Jung \& Sosik, 2002; Lim \& Ployhart, 2004; Schaubroeck, et al., 2007). The findings of this study also support the premise that routines are positively related to team effectiveness. However, the relation appears to be more complex than initially hypothesised. Relational-related interdependence was found to be a significant type of routines in enhancing team effectiveness. It shows a positive relation with both the performance of the team and team members' viability. On the other hand, routines conceptualised as task-related interdependence do not contribute to enhancing team effectiveness. This suggests that the perceived level of task-related interdependence does not contribute to the development of team performance and members' ability to work together. These findings seem to reflect the fact that, as routines involve relational-related interdependence, such routines enable members to work together effectively.

With regard to the relationship between group efficacy and team effectiveness, the results show that group efficacy is related to team members' viability. This result is in line with other studies on group efficacy and viability (e.g., Pescosolido, 2003): it seems that members of teams with a strong shared belief in their collective capacity as a team are more committed to continuing as a group. The results show no significant relationship between group efficacy and team performance as perceived by the team members. This finding stands in contrast with findings from other studies, in which a strong link between group efficacy and team performance was found (e.g., Peterson, Mitchell, Thompson, \& Burr, 1996). It is remarkable therefore that we did not find a significant relationship between group efficacy and team performance. One possible explanation for our findings is that we measured team effectiveness by using only self-ratings of performance by team members themselves. 
In future studies, researchers should use a multi-actor strategy, by asking experts, managers and team members to assess the performance of teams. The results of these studies may contribute to a deeper understanding of the relationship between group efficacy and team performance.

Finally, we found that relational-related interdependence (routines) might be an important source of group efficacy (Bandura, 1997). We found there is an indirect relationship for relational-related interdependence (routines) via group efficacy on team members' viability. This indicates that if team members have knowledge of what other members are going to do, this enhances their group efficacy or, in other words, positive beliefs about the team. Their group efficacy beliefs, in turn, enhance team members' capability to work together. Furthermore, it was hypothesised that group efficacy should partially mediate the relationship between transformational leadership and team effectiveness. Surprisingly, this effect was not found. In evaluating this result, we must take into account the fact that transformational leadership, as studied in this dissertation, was measured using 'charisma items'. Scholars who have investigated transformational leadership have distinguished four dimensions: charisma, individual consideration, intellectual stimulation and inspiration (Avolio, Bass \& Jung, 1999). A more fine-grained measurement of transformational leadership should probably be considered (e.g., different dimensions of transformational leadership), to gain a better understanding of the relation between transformational leadership, group efficacy and team effectiveness.

The current study contributes to the team effectiveness literature, by combining research on transformational leadership, routines and group efficacy. As our results show, combining different streams of research advances our understanding of the relationship transformational leadership - routines - group efficacy - team effectiveness. Moreover, our research also adds to routine theory, by extending and empirically testing routines (Becker, 2008). The results suggest that the effect of routines might be mainly due to the role of relational-related interdependence in stimulating team effectiveness (viability) via group efficacy. Thus, it may be that team members need to have some knowledge of what other members are going to do before they can develop a sense of group efficacy and work effectively as a team.

\section{Limitations and Future Directions}

Despite the potential of this study, some limitations need to be mentioned. The sample size at team level is limited. However, to date no research has investigated the question of appropriate sample size for the MSEM model (Preacher, et al., 2010). Moreover, according to Ryu and West (2009), researchers who use MSEM should consider level-specific model fit evaluation. MSEM is one of the cases in which the standard global fit evaluation has a limitation, due to the nature of multilevel data (see Ryu \& West, 2009; for level-specific methods). Future samples 
should also consider different organisations and professions, to allow generalisations to more organisational settings. This study was conducted in an educational setting; one may wonder if the results of the research at hand can be generalised to other professional organisations without any discussion. It is not yet known whether similar results would be found in other types of organisations. Furthermore, we relied on self-reports to gather our data. A problem associated with self-reports is common method variance (Spector, 2006). In order to avoid potential common method variance, future studies could use, for instance, multiple types of respondents (e.g., team managers) and multiple methods (e.g., case studies). 

General Discussion 


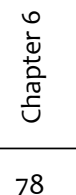


At a time when secondary vocational education is implementing Competence-Based Education ( $\mathrm{CBE}$ ) on a large scale, to adapt to the needs of students and of the labour market in a modern society, many vocational schools have recognised that interdisciplinary teacher teams are an important condition for this implementation. In order to provide students with the right competences for the labour market, different subject teachers should work and learn together and, by doing so, should be able to develop changes and improvements to ensure the effective implementation of CBE. Guided by theories from organisational, psychological and educational research, this dissertation has contributed to insights into what is important for the effective functioning of teams in an educational setting. The findings of the present dissertation highlight the importance of the development of routines, transformational leadership and group efficacy for producing effective teams.

For this research, four studies were conducted in Vocational Education and Training (VET) colleges to examine team effectiveness in secondary vocational education in the Netherlands. First, a qualitative study was conducted. In this study, we interviewed managers from a VET college, in order to address the question of how 'team effectiveness' in a vocational education context can be defined, and which factors are considered to influence the effective functioning of teams. In line with the organisational and psychological literature on team effectiveness, the managers distinguished several aspects in their definition of team effectiveness (e.g., Hackman, 1983; Kozlowski \& Ilgen, 2006; Mathieu, Maynard, Rapp, \& Gilson, 2008; ZellmerBruhn \& Gibson, 2006). Team effectiveness refers not only to performance but also to viability (members' ability to work together) and the innovative ability of the team. Findings from this study and insights from the research literature in the field of team effectiveness were used to develop a conceptual model. In this model it is assumed that routines, transformational leadership and group efficacy are factors that may potentially influence team effectiveness in a vocational education context. Team effectiveness was measured by two different outcomes: perceived team performance and viability. To test this model, data were collected by means of two surveys of team members from different VET colleges. These data were analysed in three different (or consecutive) studies, using advanced statistical techniques that took account of the multilevel structure of the model (individual level and team level). Until recently, multi-level methods have been limited, because they could not accommodate a variable affecting another variable at a higher level. As a result, each effect in the causal chain involves a variable affecting another variable at the same or lower level (Preacher, Zyphur \& Zhang, 2010). This study used Multilevel Structural Equation Modelling (MSEM) to overcome this limitation. The MSEM approach we used in the three quantitative studies (Chapters 3, 4 and 5) enabled us to investigate 'upward' effects within multilevel data. For example, the construct of group efficacy is a group level construct that has its foundations in the cognition of individual team members. In addition, the group efficacy construct that emerges from 
individual level properties reflects an 'upward' process (Kozlowski \& Klein, 2000). By using constructs such as group efficacy, this research emphasises the importance of establishing relationships between constructs at multiple levels of analysis or, in other words, how a higher level construct emerges from a lower level construct. MSEM offers the possibility of testing these complex relations between individual-level variables and team-level variables in a single research model, as well as taking into account the multilevel structure.

The findings provide evidence of the crucial role of routines and transformational leadership in enhancing team performance. When it comes to team members' viability, all three factors - routines, transformational leadership, and group efficacy - proved to be important. Furthermore, we also found an indirect relationship for routines via group efficacy on team members' viability. Next, we discuss the theoretical and practical implications of our results, as well as their limitations, and make suggestions for future research.

\section{Theoretical implications}

\section{Routines}

This study has contributed to empirical research on team effectiveness, not only by including routines as an important input factor in our model, but also by providing a conceptualisation for routines. Although the importance of routines has been discussed by many researchers from different disciplines (e.g., Becker, 2001; Cohen \& Bacdayan, 1994; Cohendet \& Lierena, 2003; Hodgson \& Knudsen, 2004; Lazaric, 2000; Pentland \& Feldman, 2008; Pentland \& Rueter, 1994), there seems to be little agreement on the definition and measurement of routines in research. As a consequence, empirical progress in research on routines is developing at a slow pace (Becker, 2005; Cohen \& Bacdayan, 1994). In this dissertation, we found that it was important to include what it is that enables team members to perform routines. Routines were therefore measured by the extent of the interrelatedness of team members. Interrelatedness is not a one-dimensional concept; it consists of members' perceived level of task-related and relational-related interdependence. Task-related interdependence refers to the pattern in which team members have to exchange information and resources to complete their collective tasks. Relational-related interdependence refers to members' expectations about how to work together as a team. The extent to which team members perceive this interdependence in a team is regarded as a measurable indicator of the extent of the development of routines.

Because empirical evidence for the association between routines and team effectiveness was still scarce, in the first quantitative study we focused on the direct effect of routines on team effectiveness (Chapter 3 ). The results showed a positive relationship with both output measures of team effectiveness: perceived team performance and the perceived 
viability of team members. These findings give support to the relation - often assumed, but not tested - between routines and team effectiveness. This also indicates that, even in organisations such as schools, where teachers traditionally work very independently of each other, routines can play an important role in enhancing team effectiveness. The direct relationships between routines and team effectiveness, as found in the first quantitative study, were partly confirmed in the other two quantitative studies, using data from the second survey (Chapters 4 and 5). Relational-related interdependence proved to be a positive predictor of team performance and team members' viability, while no association was found between task-related interdependence and both aspects of team effectiveness. As team members get to know each other on a 'relational' level, they become able to make correct predictions about their team colleagues' views and ways of working. This knowledge can help teachers to work together effectively. A possible explanation for not finding an association between task-related interdependence and both aspects of team effectiveness is the fact that the sample size at team level of the second survey is limited. It should, however, be noted that, to date, no research has investigated the question of appropriate sample size for the MSEM model (Preacher et al., 2010). In addition, given the autonomy and often isolated position of teachers, task-related interdependence may be a difficult issue (Caluwé \& Vermaak, 2004). Task-related interdependence means that teachers are dependent on each other for carrying out their work successfully (Van der Vegt, Emans, \& van de Vliert, 1998). This is the case, for example, when teachers need to obtain information or advice from each other, in order to be able to carry out their work effectively. Many studies devote attention to the isolated position of teachers, as a result of which task interdependence has difficulty getting off the ground (Caluwé \& Vermaak, 2004). This might help to explain why relationalrelated interdependence may be especially critical to teacher teams. These findings seem to reflect the fact that, as routines involve relational-related interdependence, such routines enable teachers to work together effectively.

Besides examining the direct effects of routine on team effectiveness, we also examined the indirect effects, by including group efficacy as a mediator in our model. In the literature, group efficacy is increasingly associated with team effectiveness. Group efficacy can be defined as "a group's collective estimate regarding the group's ability to perform a task objective" (Gibson, 2001, p. 790). A team that shares the belief that it can be successful at a particular task has a much greater likelihood of actually succeeding (Bandura, 1997). The findings show that group efficacy partially mediated the relationship between relational-related interdependence and team members' viability. These findings indicate that group efficacy can play an important role in mediating the relationship between routines and one of the outcome measures of team effectiveness as perceived by teachers. This indicates that the impact that routines may have on the effectiveness of teams is partly indirect and, as evidenced in this study, can be 
explained by increased group efficacy beliefs. Although group efficacy beliefs may not be the sole mechanism through which routines affect team effectiveness, it is indeed a significant mechanism, and what is as important, a mechanism that may be affected by routines through fostering relational interdependence.

\section{Transformational leadership}

Although many studies have examined the relationship between transformational leadership and effectiveness at the individual and organisational level of analysis (e.g., Lowe Kroeck, \& Sivasubramaniam, 1996; Patterson, Fuller, Kester, \& Stringer, 1995), relatively few studies have examined the impact of transformational leadership on team effectiveness. In the third quantitative study (Chapter 5), we therefore examined the impact of transformational leadership on team effectiveness, using the data from the second survey of VET teachers. By including this variable in our model, we examined the relationship between routines and transformational leadership as input factors on the one hand, and perceived team effectiveness as outcome factor on the other hand. We also examined the role of group efficacy in mediating the relationship between the input and output factors in our model.

The findings show that transformational leadership is positively related to team effectiveness, both at team (team performance) and individual level (viability). Although we also hypothesised that group efficacy should partially mediate the relationship between transformational leadership and team effectiveness, the findings did not, however, confirm our expectation. In evaluating this result, we must take into account the fact that transformational leadership is a multi-dimensional construct, consisting of several sub-dimensions, namely charisma, individual consideration, intellectual stimulation and inspirational motivation (Avolio, Bass, \& Jung, 1999). In this study, we measured transformational leadership only using 'charisma items'. Meta-analytic results have indicated that charisma is strongly associated with measures of effectiveness (Lowe, Kroeck, \& Sivasubramaniam, 1996). As far as group efficacy is concerned, scholars have argued that transformational leadership influences group efficacy, especially through role modelling and verbal persuasion (Podsakoff, Mackenzie, Moorman, \& Fetter, 1990; Schaubroeck, Lam, \& Cha, 2007). It can be argued that the fourth dimension of transformational leadership - inspirational motivation - is a form of verbal persuasion. Bass (1985) stated that leaders use inspirational appeals and emotional talks to generate follower motivation, to transcend self-interest for the good of the team. When leaders communicate positively and are encouraging, members are likely to feel more confident about the functioning of the team. For future research, it would be interesting to further examine whether it is indeed the inspirational dimension of transformational leadership that makes it an effective leadership style for enhancing group efficacy beliefs. 


\section{Group efficacy}

Although the relation between routines, transformational leadership, group efficacy and team effectiveness may not be causal at all, our research does imply that effective teamwork does not take place merely by putting together a number of teachers. This study shows that, in terms of performance and viability, effective teams are related to high levels of relationalrelated interdependence (routines), high levels of transformational leadership and high levels of group efficacy. However, despite the fact that group efficacy partly mediated the relation between relational-related interdependence (routines) and viability, group efficacy itself turned out to be related only to viability and not to team performance. This finding seems in contrast with those of other studies, in which a strong link between group efficacy and team performance was found (e.g., Peterson, Mitchell, Thompson, \& Burr, 1996). However, also modest and complex relations were found between group efficacy and team performance, in which various group processes interact (Campion, Medsker, \& Higgs, 1993; Earley, 1993; Guzzo, Yost, Campbell, \& Gregory, 1993; Prussia \& Kinicki, 1996). Gibson (1999) investigated different interaction variables that might influence the relation between group efficacy and team performance. For example, when task uncertainty was high, team members worked independently of each other and collectivism was low, Gibson found no relation between group efficacy and team performance. When task uncertainty was low, team members had to work together closely and collectivism was high, a significant positive relationship was indeed found between group efficacy and team performance. These group processes help in the exchange of information, which, again, has an effect on group efficacy and the relation with team performance. The findings of Gibson (1999), just like those of Zaccaro, Blair, Peterson and Zazanis (1995) and Lee, Tinsley and Bobko (2002), provide a reason to examine whether a group process possibly occurs as moderator of the relation between group efficacy and team performance. This is of interest for further research.

\section{Limitations}

As with all research, there are some limitations to this study that need to be addressed. First of all, we relied on self-reports to gather our data. The concepts used in the multi-level analyses were measured, using the reports of the same team members. The issue here is not the fact that these are the perceptions of team members, since it can be argued that, in this setting, team members are first-hand, and therefore reliable, observers. However, the concepts were subject to internal correlation, which raises the problem of common method biases for this study. Even though we investigated mediation effects, which reduce the likelihood of common method bias interfering with the interpretation of the results (Podsakoff, Mackenzie, Lee \& Podsakoff, 2003), in future research, different sources for measuring concepts should be used, to reduce the common method bias. For instance, by having the team leaders rate certain team outcomes. Due to the lack of sufficient respondents in our study, we could not use the 
mangers' data to reduce the common method bias. For future research, it is recommended that data be collected from multiple sources, for instance from both the team members and team leaders, or more objective data be used, such as students' achievement and the number of dropouts.

Secondly, all the datasets used for this research were cross-sectional, meaning that all the data were collected at the same point in time. As a result, it is not possible to draw firm conclusions on causality, and the results may not be unidirectional. In Chapters 4 and 5, where we examined the mediation effect of group efficacy, causality may be reversed. The causal ordering of routines and group efficacy may be just the opposite of what has been put forward, or relations are reciprocal. For example, teams who believe in their group's efficacy will put more effort into the development of relational-related interdependence (routines). This implies that, to fully understand team effectiveness, it is important to understand the dynamic nature of teams. It suggests that a study on teacher teams may need a more dynamic model, such as the Input-Mediator-Outcome-Input (IMOI) approach suggested by Ilgen, Hollenbeck, Johnson and Jundt (2005), in order to deal with issues of time and development. The IMOI model implies the existence of a cycle and feedback from outcome to mediators; for example, a change in outcome will influence the mediators. The idea behind this is that the state of a team at any one time is especially influenced by its progress over time, which is why a team usually changes its processes based on outcomes. The IMOI model is therefore also referred to as a developmental model. This kind of model could further help in developing an in-depth understanding of the relationship between routines, transformational leadership, group efficacy and team effectiveness.

Thirdly, although this study shows that routines have a positive effect on effective team functioning, the downside of routines is less clear. Could routines also have negative effects? And for what kind of team outcomes and under what conditions? It is possible that routines that give a team stability also generate resistance to change. Thus, when team members have routines, would these hamper team-level outcomes, such as team adaptability and innovation? Similarly, if team members have routines which are dysfunctional, they might very well contribute to ineffective performance. More research is needed to examine the different, both positive and negative, effects of routines. In order to increase our understanding of the differential effects of routines on team effectiveness, scholars should include other outcome measures (e.g., team innovation) in their research on team effectiveness.

Fourthly, it may be worthwhile exploring other mediators to investigate the relationship between routines and transformational leadership and team effectiveness. The present dissertation identified group efficacy as a mediator through which routines and transformational leadership are related to team effectiveness. Given that group efficacy can motivate teachers to perform better as a team (Bandura, 1997), it can be viewed as a 'motivational facilitator'. Future research may investigate whether other motivational 
or cognitive states also mediate the relationship between routines and transformational leadership and team effectiveness, such as shared work values. Shared work values can help teachers perceive and interpret their work compatibly (Cannon-Bowers, Sales, \& Converse, 1993). Work values can be defined as internalised beliefs about what is worth doing at work. Team members must hold similar work values to draw common interpretations, in order to reach effective decisions (Cannon-Bowers \& Sales, 2001). In this, shared work values might have a strong effect on team effectiveness and mediate the influence that routines and transformational leadership have on team performance and viability.

Finally, the study is restricted to the measuring of the transformational leadership element of charisma. A more fine-grained measurement of transformational leadership should probably be considered (e.g., different dimensions of transformational leadership), to gain a better understanding of the relation between transformational leadership, group efficacy and team effectiveness. Moreover, Bass (1999) suggested that successful transformational leaders too employ transactional leadership behaviours in daily practice. Transactional leadership behaviours are those that are associated with 'transactions' between leaders and followers, and are often associated with the clarification of goals and objectives, and with providing recognition once goals have been achieved. Bass (1985) developed a model of transformational leadership that conceptualised transactional and transformational leadership forms as separate but interdependent dimensions. A 'fundamental' proposition of transformational-transactional leadership theory that has often been discussed but little tested is the augmentation effect. The augmentation effect essentially argues that transformational leadership builds on transactional leadership styles. In view of the statement that transformational leadership complements transactional leadership and that effective leaders often supplement transactional leadership with transformational leadership, future research should also try to test this augmentation effect.

\section{Practical implications}

Even though research on the effectiveness of teacher teams in Dutch vocational education is still needed, the results of the present research have important practical implications. In general, routines such as relational-related interdependence seem to be important for team effectiveness. The question therefore is "How can we foster the development of teachers' relational-related interdependence, to optimise effective team functioning?" A common suggestion for managers is to stimulate interaction between teachers, in order to develop relational-related interdependence. However, given the autonomy and often isolated position of teachers, interaction between teachers can be a difficult issue (Caluwé \& Vermaak, 2004; Hanson, 1993). The question is therefore how to ensure that interaction is encouraged. The managers in the first study (Chapter 2) underlined the importance of interaction between teachers, which they link to the working environment, which should be arranged in a way that 
promotes interaction between teachers. They indicated that teachers' workplaces should be in proximity to each other, because this stimulates communication. In addition, there is also the question of how to ensure that the forming of routines does not prove to be limited to relational interdependence, but will also bring about task interdependence on issues. Task interdependence occurs only when teachers need each other, in other words, when there is cooperation. The stronger the task interdependence between people, the more interaction there is and the more they feel responsible for each other's work (Champion, Medsker, \& Higgs, 1993, Kiggundu, 1983). In this regard, we suggest that, especially when teams are just getting started, team meetings should involve a programme in which members are made aware of each other's roles and responsibilities in the team. Another way of promoting task interdependence is to provide team-level appraisals. This promotes a feeling of task interdependence with all team members being responsible to each other as everyone shares the success or failures.

Moreover, the first study (Chapter 2) shows that several team composition factors seem to be important for effective team functioning, including team size and team homogeneity. According to the managers, an effective team consists of six to ten teachers. The managers also indicated that teachers in a team should share the same educational view, and a mix of young and older, male and female is preferred. In addition, ensuring a certain degree of stability in team composition or members' experience of working together may also stimulate the formation of routines, which will eventually lead to improved team performance.

Finally, this study demonstrates that transformational leadership may be valuable for effective team functioning. It leads to a shared vision and trust within the team. When all team members are focused on a common goal, this may stimulate the team's development. When selecting school managers for teacher teams, VET colleges could look for transformational leadership potential by evaluating leaders for this potential, using assessment centres. However, most managers of teacher teams face the challenging task of leading a team, without having much experience of teams. It would therefore seem advisable for managers to receive training in transformational leadership, or for training situations to be created in which both the manager and teacher participate. The findings of our study suggest that these investments in leadership development can make teams and, in turn, VET colleges become more effective. 


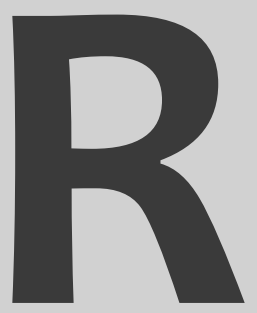

References 


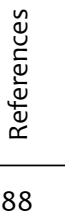


Avolio, B. J., Bass, B. M., \& Jung, D. I. (1999). Re-examining the components of transformational and transactional leadership using the Multifactor Leadership Questionnaire. Journal of Occupational and Organizational Psychology, 72, 441-462. doi: 10.1348/096317999166789

Avolio, B. J., Jung, D. I., Murry, W., \& Sivasubramaniam, N. (1996). Building highly developed teams: Focusing on shared leadership processes, efficacy, trust and performance. Advances in Interdisciplinary Studies on Work Teams, 3, 173-209.

Bandura, A. (1997). Self-efficacy: The exercise of control. New York: Freeman \& Company.

Bandura, A. (1982). Self-efficacy mechanism in human agency. American Psychologist, 37, 122147.

Bass, B. M. (1985). Leadership and performance beyond expectations. New York: Free Press.

Bass, B. M., \& Avolio, B. J. (1994). Improving organizational effectiveness through transformational leadership. Thousand Oaks, CA: Sage.

Bass, B. M., Avolio, B. J., Jung, D. I., \& Berson, Y. (2003). Predicting unit performance by assessing transformational and transactional leadership. Journal of Applied Psychology, 88, 207-218. doi: 10.1037/0021-9010.88.2.207

Basoski, I., Van den Hoek, L., \& Massier, C. (2009). Op weg naar 2010..de finale. Ede, The Netherlands: MBO 2010. Accessed on May 14, 2010, at http://www.mbo2010.nl/ index.cfm/t/Publicaties/vid/52252123-3FFA-497D-95E357DoF60619EB

Becker, M. C. (2008). Handbook of organizational routines. UK: Edward Elgar Publishing.

Becker, M. C. (2005). A Framework for applying organizational routines in empirical research: linking antecedents, characteristics and performance outcomes of recurrent interaction patterns. Industrial and Corporate Change, 14(5), 817-846. doi: 10.1093/ icc/dtho72

Becker, M. C. (2004). Organizational routines: a review of the literature. Industrial and Corporate Change, 13(4), 643-678. doi: $10.1093 / \mathrm{icc} / \mathrm{dth} 026$

Becker, M. C. (2001). The role of routines in organizations: An empirical and taxonomic investigation. PhD Thesis, UK: Judge Institute of Management: University of Cambridge.

Becker, M. C., \& Lazaric, N. (2009). Organizational routines advancing empirical research. UK: Edward Elgar Publishing.

Bentler, P. M., \& Bonnett, G. (1980). Significance tests and goodness of fit in the analysis of covariance structures. Psychological Bulletin, 88(3), 588-606. doi: 10.1037/00332909.88.3.588

Biemans, H., Nieuwenhuis, L., Poell, R., Mulder, M., \& Wesselink, R. (2004). Competence-based VET in the Netherlands: Background and pitfalls. Journal of Vocational Education and Training, 56(4), 523-538. doi: 10.1080/13636820400200268

Bliese, P. D. (2000). Within-group agreement, non-independence, and reliability: Implications for data aggregation and analysis. In K.J. Klein \& S.W.J. Kozlowski (Eds.), Multilevel theory, research, and methods in organizations (pp. 349-381). San Francisco, CA: Jossey-Bass.

Burns, J. M. (1978). Leadership. New York: Harper \& Row.

Caluwé, L. de, \& Vermaak, H. (2002). Leren veranderen. Een handboek voor de veranderkundige. Alphen aan de Rijn: Samson.

Cannon-Bowers, J. A., \& Sales, E. (2001). Reflections on shared cognition. Journal of Organizational Behavior, 22, 195-202. doi: 10.1002/job.82

Cannon-Bowers, J. A., Sales, E., \& Converse, S. A. (1993). Shared Mental Models in expert team decision making. In N.J. Castellan (Eds), Current issues in individual and group decision making (pp. 221-246). Hillsdale, NJ: Erlbaum.

Campion, M. A., Medsker, G. J., \& Higgs, A. C. (1993). Relations between work groups characteristics and effectiveness: implications for designing effective work groups. Personnel Psychology, 46(4), 823-847. doi: 10.1111/j.1744-6570.1993.tb01571.x 
Clement, M., \& Vandenberghe, R. (2000). Teachers' professional development: a solitary or collegial (ad)venture? Teaching and Teacher Education, 16, 81-101. doi: 10.1016/S0742051X(99)00051-7

Cohen, M. D. \& Bacdayan, P. (1994). Organizational routines are stored as procedural memory: Evidence from a laboratory study. Organizational Science, 5(4), 554-568.

Cohen, S. G. \& Bailey, D. E. (1997). What Makes Teams Work: Group Effectiveness Research from the shop floor to the Executive Suite. Journal of Management, 23(3), 239-290. doi: $10.1177 / 014920639702300303$

Cohendet, P., \& Lierena, P. (2003). Routines and incentives: The role of communities in the firm. Industrial and Corporate Change, 12, 271-297. doi:10.1093/icc/12.2.271

Conley, S., Fauske, J., \& Pounder, D. G. (2004). Teacher work group effectiveness. Educational Administration Quarterly, 40(5), 663-703. doi: 10.1177/0013161X04268841

Conrad, C., \& Poole, M.S. (2002). Strategic Organizational Communication in Global economy. Orlando: HarcourtPublishers.

Crow, G. M., \& Pounder, D. G. (2000). Interdisciplinary Teacher Teams: Context, Design, and Process. Educational Administration Quarterly, 36(2), 216-254. doi: 10.1177/0013161X00362004

De Dreu, C. K. W., \& Weingart, L. R. (2003). Task versus relationship conflict, team performance and team member satisfaction: A meta-analysis. Journal of Applied Psychology, 88(4), 741-749. doi: 10.1037/0021-9010.88.4.741

De Hoogh, A. H. B., den Hartog, D.N., \& Koopman, P. L. (2004). The development of the CLIO:A questionnaire for measuring charismatic leadership. Gedrag \& Organisatie, 17, 354-382.

Dionne, D. S., Yammarino, F. J., Atwater, L. E., \& Spangler, W. D. (2004). Transformational leadership and team performance. Journal of Organizational Change Management, 17(2), 177-193. doi:10.1108/09534810410530601

Dosi, G., Nelson, R. R., \& Winter, S. G. (2000). Introduction: The Nature and Dynamics of Organizational Capabilities. In G. Dosi, R.R. Nelson, \& S.G. Winter (Eds.), The Nature of Dynamics of Organizational Capabilities (pp. 1 - 22). Oxford: Oxford University Press.

Early, P.C. (1993). East meets west meets mideast: further explorations of collectivistic and individualistic work groups. Academy of Management Journal, 36, 319-348.

Edmondson, A. C., Bohmer, R. M., \& Pisano, G. P. (2001). Disrupted Routines: Team learning and new technology implementations in hospitals. Administrative Quarterly, 46 (4), 685-716.

Ellemers, N., Kortekaas, P., \& Ouwerkerk, J. W. (1999). Self-categorization, commitment to the group and group self-esteem as related but distinct aspects of social identity. European Journal of Social Psychology, 29(2-3), 371-389. doi: $10.1348 / 014466600164633$

Feldman, M. S. (2003). A performative perspective on stability and change in organizational routines. Industrial and Corporate change, 12 (4), 727-752. doi: 10.1093/ICC/12.4.727

Gersick, C. J. G. \& Hackman, R. (1990). Habitual routines in task-performing groups. Organizational Behavior and Human Decision Processes, 47(1), 65. doi: 10.1016/07495978(90)90047-D

Gibson, C. B. (2001). Me and us: Differential relationships among goal-setting training, efficacy, and effectiveness at the individual level and team level. Journal of Organizational Behavior, 22, 789-808. doi: 10.1002/job.114

Gibson, C.B. (1999). Do they do what they believe they can? Group efficacy and group effectiveness across tasks and cultures. Academy of Management Journal, 42, 138152.

Gittell, J. H. (2002). Coordinating Mechanisms in Care Provider Groups: Relational Coordination as a mediator and input uncertainty as a moderator of performance effects. Management of Science, 48(11), 1408-1426. 
Goddard, R.D., Hoy, W.K., \& Woolfolk Hoy, A.E. (2000). Collective teacher efficacy: Its meaning, measure, and effect on student achievement. American Education Research Journal, 37 (2), 479-507. doi: 10.3102/00028312037002479

Gronn, P. (2000). Distributed properties: a new architecture for leadership. Educational Management \& Administration, 28 (3), 317-338. doi: 10.1177/0263211X000283006

Gully, S. M., Incalcaterra, K. A., Joshi, A., \& Beauien, J. M. (2002). A Meta-analysis of team efficacy, potency, and performance: Interdependence and level of analysis as moderators of observed relationships. Journal of applied psychology, 87(5), 819-832. doi: $10.1037 / 0021-9010.87 .5 .819$

Guzzo, R. A. \& Dickson, M.W.(1996). Teams in organizations: Recent research on performance and effectiveness. Annual Review of Psychology, 47, 307-338. doi: 10.1146/annurev. psych.47.1.307

Guzzo, R. A., \& Shea, G. P. (1992). Group performance and intergroup relations in organizations. In Dunnette M.D., Houg L.M. (Eds.), Handbook of industrial and organizational psychology (Vol. 3 pp, 269-313). Palo Alto: Consulting Psychologists Press.

Guzzo, R. A., Yost, P.R., Campbell, R.J., \& Shea, G. P. (1993). Potency in groups: Articulating a construct. British Journal of Social Psychology, 32(1), 87-106.

Hackman, J. R. (2002). Leading teams: Setting the stage for great performances. Boston: Harvard Business Press.

Hackman, J. R. (ed) (1990). Groups that work (and those that don't). San Francisco: JosseyBass.

Hackman, J. R. (1983). A normative model of work team effectiveness (Tech. Rep. No. 2). New Haven, United States: Yale University, Research program on Group Effectiveness.

Hackman, J. R. (1987). The design of work teams. In J.W. Lorsch (ed.), Handbook of organizational behavior (pp.315-342). Englewood Cliffs, NH: Prentice Hall.

Hackman, J. R., \& Oldham, G. R. (1980). Work redesign. Reading, MA.: Addison Wesley.

Hodgson, G. M. (2008). The concept of a Routine. In M. C. Becker (Eds.), Handbook of organizational routines. UK: Edward Elgar Publishing.

Hodgson, G. M. (2003). The Mystery of the Routine: The Darwinian Destiny of An Evolutionary Theory of Economic Change. Revue Économique, 54(2), 355-84. doi : 10.3917/ reco.542.0355

Hodgson, G. M., \& Knudsen, T. (2004). The complex evolution of a simple traffic convention: the function and implications of habit. Journal of Economic Behavior and Organization, 54, 19-47. doi: 10.1016/j.jebo.2003.04.001

House, R. J., \& Shamir, B. (1993). Toward an integration of transformational, charismatic and visionary theories of leadership. In M. Chemmers, \& R. Ayman (Eds.), Leadership: Perspectives and research directions (pp. 81-107). New York: Academic Press.

Howell, J. M., \& Higgens, C. A. (1990). Champions of Technological Innovation. Administrative Science Quarterly, 35(2), 317-341.

Hox, J. J. (2002). Multilevel analysis: Techniques and applications. Mahwah, New Jersey: Lawrence Erlbaum and Associates.

Hu, L.-T., \& Bentler, P. M. (1999). Cutoff criteria for fit indexes in covariance structure analysis: Conventional criteria versus new alternatives. Structural Equation Modeling, 6, 1-55. doi: $10.1080 / 10705519909540118$

Ilgen, D. R. 1999. Teams embedded in organizations-Some implications. American Psychologist, 54(2): 129-139. doi: 10.1037/0003-066X.54.2.129

Ilgen, D. R., Hollenbeck, J. R., Johnson, M., \& Jundt, D. (2005). Teams in organizations: From Input-Process-Output models to IMOI models. Annual Review of Psychology, 56(1), 517-543. doi:10.1146/annurev.psych.56.091103.070250

James, L. R. (1982). Aggregation bias in estimates of perceptual agreement. Journal of Applied Psychology, 67, 219-229.doi: 10.1037/0021-9010.67.2.219

Judge, T. A., \& Piccolo, R. F. (2004). Transformational and transactional leadership: A metaanalytic test of their relative validity. Journal of Applied Psychology, 89, 755-768. doi: 10.1037/0021-9010.89.5.755 
Jung. D. I., \& Sosik, J. J. (2002). Transformational leadership in work groups: The role of empowerment, cohesion, and collective efficacy on perceived group performance. Small Group Research, 33, 313-336. doi: 10.1177/1049640203003002

Kiggundu, M.N. (1983). Task interdependence and job design: Test of a theory. Organizational behavior and human performance, 31, 145-172. doi: 10.1016/0030-5073(83)90118-6

Klein, K.J., \& Kozlowski, S.W.J. (ed) (2000). Multilevel theory, research, and methods in organizations: Foundations, extensions, and new directions. San Francisco: JosseyBass.

Klimoski, R., \& Mohammed, S. (1994). Team mental model: construct or metaphor? Journal of Management, 20 (2), 403-437. doi: 10.1016/0149-2063(94)90021-3

Kozlowski, S. W. J., \& Bell, B. S. (2003). Work groups and teams in organizations. In W. C. Borman, D. R. Ilgen, \& R. J. Klimoski (Eds.), Handbook of psychology: Industrial and organizational psychology (pp. 333-375). Hoboken, NJ: John Wiley \& Sons Inc.

Kozlowski, S. W. J., \& Ilgen, D. R. (2006). Enhancing the Effectiveness of Work Groups and Teams. Psychological Science in the Public interest, 7(3), 77-124. doi: 10.1111/j.15291006.2006.00030.x

Krull, J. L. \& MacKinnon, D. P. (2001). Multilevel Modeling of individual and group level mediated effects. Multivariate Behavioral Research, 36 (2), 249-277. doi: 10.1207/ S15327906MBR3602_06

Lazaric, N. (2000). The role of routines, rules and habits in collective learning: Some epistemological and ontological considerations. European Journal of Economic and Social Systems, 14, 157-171.

Lee, C., Tinsley, C.H., \& Bobko, P. (2002). An investigation of the antecedents and consequences of group-level confidence. Journal of Applied Social Psychology, 32, 1628-1652. doi: 10.1111/j.1559-1816.2002.tb027.x

Lim, B. C., \& Ployhart, R. E. (2004). Transformational leadership: Relations for the five-factor model and team performance in typical and maximum contexts. Journal of Applied Psychology, 89, 610-621. doi: 10.1037/0021-9010.89.4.610

Lindsley, D. H., Brass, D. J., Thomas, J. B.(1995). Efficacy-Performance Spirals: A multilevel perspective. Academy of management review, 20 (3), 645-678.

Lisbon European Council (2000). Presidency Conclusions, 23 and 24 March 2000.

Lowe, K. B., Kroeck, K. G., \& Sivasubramaniam, N. (1996). Effectiveness correlates of transformational and transactional leadership: A meta-analytic review of the MLQ literature. Leadership Quaterly, 7, 385-425. doi: 10.1016/S1048-9843(96)90027-2

March, J. G. (1997). Understanding how decisions happen in organizations. In Z. Shapira (Eds.), Organizational decision making (pp. 9-32 ). New York: Cambridge University Making.

March, J. G. (1991). Exploration and exploitation in organizational learning. Organizational Science, 2, 71-87.

Marks, M. A., Mathieu, J. E., \& Zaccaro, S. J. (2001). A temporally based framework and taxonomy of team processes. The Academy of Management Review, 26(3), 356-376.

Mathieu, J., Maynard, M. T., Rapp, T., \& Gilson, L. (2008). Team effectiveness 1997-2007: A review of recent advancements and a glimpse into the future. Journal of Management, 34(3), 410-476. doi: 10.1177/0149206308316061

Mayrowetz, D., Murphy, J., Louis, K. S., \& Smylie, M. A. (2007). Distributed leadership as work redesign: Retrofitting the Job Characteristics model. Leadership and Policy in Schools, 6(1), 69 - 101. doi: 10.1080/15700760601091275

MBO-raad (2009). Professioneel statuut. Woerden: mbo-raad.

McGrath, J. E. (1964). Social psychology: A brief introduction. New York, NY: Holt, Rinehart \& Winston.

Mclntyre, R. M., \& Sales, E. (1995). Measuring and managing for team performance: Emerging principles from complex environments. In R. Guzzo \& E. Salas (Eds.), Team effectiveness and decision making in organizations (pp. 149-203). San Francisco, CA: Jossey-Bass. 
Miles, M.B., \& Huberman, A.M. (1994). Qualitative data analysis. Thousand Oaks, CA: Sage.

Mischel, L. J., \& Northcraft, G. B. (1997). "I think we can, I think we can. ..": The role of efficacy beliefs in group and team effectiveness. In B. Markovsky, M.J. Lovaglia, \& R. Simon (Eds.), Advances in group processes (Vol. 14, pp. 177-197). Greenwich, CT: JAI.

Nelson, R. R. \& Winter, S. (1982). An evolutionary theory of economic change. Cambridge, MA: Belknap Press of Harvard University Press.

Newmann, F. M., King, M. B., \& Youngs, P. (2001). Professional developments that address school capacity: lessons from Urban Elementary School. American Journal of Education, 108(4), 259-299.

Patterson, C., Fuller, J.B., Kester, K., \& Stringer, D.Y. (1995). A meta-analytic examination of leadership style and selected compliance outcomes. Paper presented at the $10^{\text {th }}$ Annual Conference of the Society for Industrial and Organizational Psychology, Orlando, FL.

Paulus, P. B. (2000). Groups, Teams, and Creativity: The Creative Potential of Idea-generating Groups. Applied Psychology: An International Review, 49(2), 237. doi: 10.1111/14640597.00013

Pelkmans, T., \& Smit, F. (1999). Zelfsturende teams: een orienterend onderzoek in scholen voor beroepsonderwijs. Mesofocus, 19, 2-7.

Pentland, B. T., \& Feldman, M. S. (2008). Issues in empirical field studies of organizational routines. In M. C. Becker (Eds.), Handbook of organizational routines. UK: Edward Elgar Publishing.

Pentland, B. T., \& Feldman, M. S. (2005). Organizational routines as a unit of analysis. Industrial Corporate Change, 14(5), 793-815. doi: $10.1093 /$ icc/dtho70

Pentland, B. T., \& Rueter, H. (1994). Organizational routines as grammars of action. Administrative Sciences Quarterly, 39, 484-510.

Pescosolido, A. T. (2003). Group efficacy and group effectiveness: The effects of group efficacy over time on group performance and development. Small Group Research, 34, 20-42. doi: $10.1177 / 1046496402239576$

Pescosolido, A. T. (2001). Informal leaders and the development of group efficacy. Small Group Research, 32, 74-93. doi: 10.1177/104649640103200104

Peterson, R. S., \& Behfar, K. J. (2003). The dynamic relationship between performance feedback, trust, and conflict in groups: A longitudinal study. Organizational Behavior and Human Decision Processes, 92, 102-112. doi: 10.1016/S0749-5978(03)00090-6

Podsakoff, P.M., Mackenzie, S.B., Lee, J., \& Podsakoff, N. P. (2003). Common method biases in behavioral research: A critical review of the literature and recommended remedies. Journal of Applied Psychology, 88(5), 879-903. doi: 10.1037/0021-9010.88.5.879

Podsakoff, P. M., MacKenzie, S. B., Moorman, R., \& Fetter, R. (1990). The impact of transformational leader behaviors on employee trust, satisfaction, and organizational behaviors. Leadership Quarterly, 1, 107-142. doi: 10.1016/1048-9843(90)90009-7

Porter-O'Grady, T. \& Wilson, C.K. (1998). The health care TEAM book. St. Louis: Mosby.

Preacher, K. J.., \& Kelley, K. (2011). Effect Size Measures for Mediation Models: Quantitative Strategies for Communicating Indirect Effects. Psychological Methods, 16(2), 93-115. doi: $10.1037 / a 0022658$

Preacher, K. J., Zyphur, M. J., \& Zhang, Z. (2010). A General Multilevel SEM Framework for assessing multilevel mediation. Psychological Methods, 15 (3), 209-233. doi: 10.1037/ a0020141

Prussia, G.E., \& Kinicki, A.J. (1996). A motivational investigation of group effectiveness using social-cognitive theory. Journal of Applied Psychology, 81, 187-198. doi: 10.1037/00219010.81.2.187

Ritzen, H. (2004). Zinvolle leerwegen. Actieonderzoek naar innovatieve leeromgevingen voor ROC-leerlingen van kwalificatieniveaus 1 en 2. Soest: Nelissen.

Ryu, E., \& West, S. G. (2009). Level-Specific Evaluation of Model fit in Multilevel Structural Equation Modeling. Structural Equation Modeling, 16, 583-601. doi: 10.1080/10705510903203466 
Sales, E., Goodwin, G. F., \& Burke, C. S. (2008). Team effectiveness in complex organizations. Cross-disciplinary perspectives and approaches. New York, NY: Taylor \& Francis group.

Salas, E., Sims, D. E., \& Burke, C. S. (2005). Is there a "Big Five" in teamwork? Small Group Research, 36(5), 555-599. doi: 10.1177/1046496405277134

Schaubroeck, J., Lam, S. S. K., \& Cha, S. E. (2007). Embracing Transformational leadership: Team values on the impact of leader behavior on Team performance. Journal of Applied Psychology, 92(4), 1020-1030.

Schippers, M. C., den Hartog, D. N., Koopman, P. L., Van Knippenberg, D. (2008). The role of transformational leadership in enhancing team reflexivity. Human Relations, 61(11), 1593-1616. doi: 10.1177/0018726708096639

Schyns, B., \& Von Collani, G. (2002). A new occupational self-efficacy scale and its relation to personality constructs and organizational variables. European journal of work and organizational psychology, 11 (2), 219-241. doi: 10.1080/13594320244000148

Scribner, J. P., Sawyer, R. K., Watson, S.T., \& Myers, V. L. (2007). Teacher Teams and Distributed Leadership: A study of Group Discourse and Collaboration. Educational Administration Quarterly, 43(1), 67-100. doi: 10.1177/0013161x06293631

Shea, G.P. , \& Guzzo, R. A. (1987). Group effectiveness: What really matters? Sloan Management Review, 28, 25-31.

Shin, S. J., \& Zhou, J. (2003). Transformational leadership, conservation, and creativity: Evidence from Korea. Academy of Management Journal, 46(6), 703-714.

Somech, A., \& Bogler, R. (2002). Antecedents and Consequences of Teacher Organizational and Professional Commitment. Educational Administration Quarterly, 38(4), 555-77. doi: $10.1177 / 001316102237672$

Somech, A., \& Drach-Zahavy, A. (2007). Schools as team-based organizations: A structureprocess-outcomes approach. Group Dynamics-Theory Research and Practice, 11(4), 305-320. doi: 10.1037/1089-2699.11.4.30

Spector, P. E. (2006). Method Variance in Organizational Research: Truth or Urban Legend? Organizational Research Methods, 9 (2), 221-232. doi: 10.1177/1094428105284955

Spillane, J. P., Halverson, R., \& Diamond, J. B. (2001). Investigating School Leadership Practice: A Distributed Perspective. Educational Researcher, 30 (3), 23-28.

Stewart, G. L. (2006). A meta-analytic review of relationship between team design features and team performance. Journal of Management, 32(1), 29-55. doi: $10.1177 / 0149206305277792$

Stoker, J. I. (2007). Effects of team tenure and leadership in self-managing teams. Personnel Review, 37(5), 564-582.

Stoker, J. I. (1999). Leidinggeven aan zelfsturende teams. Assen: Van Gorcum.

Streumer, J. \& Van der Klink, M. (2004). Leren op de werkplek. Den Haag: Reed Business Information.

Truijen, K. J. P., Sleegers, P. J. C., Meelissen, M.R.M., \& Nieuwenhuis, A.F.M. (in progress).

Tucker, L. R., \& Lewis, C. (1973). A reliability coefficient for maximum likelihood factor analysis. Psychometrika, 38 (1), 1-10. doi: 10.1007/BF02291170

94 Van den Bossche, P. (2006). Minds in Teams. The Influence of Social and Cognitive Factors on Team Learning. Maastricht: Datawyse.

Van der Meijden, A., Westerhuis, A., Huisman, J., Neuvel, J., \& Groenenberg, R. (2009). Beroepsonderwijs in verandering: op weg naar competentiegericht onderwijs. De vierde meting van de CGO Monitor. Amsterdam, The Netherlands: Expertisecentrum Beroepsonderwijs. Accessed on May 14, 2010 at http://www.mbo2010.nl/index. cfm/t/Onderzoek/vid/oAB12E42-17A4-A597-D99DCC735A412A77

Van Merriënboer, J.J.G., Van der Klink, M.R., \& Hendriks, M. (2002). Competenties: van complicaties tot compromis. Over schuifjes en begrenzers. Den Haag: Onderwijsraad.

Van Offenbeek, M. (2001). Processes and outcomes of team learning. European Journal of Work and Organizational Psychology, 10(3), 303-317. doi: 10.1080/13594320143000690 
Van der Sanden, J., De Bruijn, E., \& Mulder, R. H. (2003). Ontwikkelingen in het onderzoek op het terrein van het beroepsonderwijs (Developments in research in vocational education). In M. Mulder, R. Wesselink, H.J.A. Biemans, A.F.M. Nieuwenhuis \& R.F.Poell (Eds.), Competentiegericht beroepsonderwijs. Gediplomeerd, maar ook bekwaam?, (pp. 79-91). Groningen: Wolters-Noordhoff.

Van der Vegt, G., \& Bunderson, J. S. (2005). Learning and performance in multidisciplinary teams: the importance of collective team identification. Academy of Management Journal, 48 (3), 532-547.

Van der Vegt, G., Emans, B., \& Van de Vliert, E. (1998). Motivating effects of task and outcome interdependence in work teams. Group and Organization Management, 23, 24-143. doi: $10.1177 / 1059601198232003$

Van de Venne, L. Felix, C., \& Vermeulen, A. (2001). Zelfsturende teams in ROC's: een studie naar de ontwikkeling van zelfsturende teams binnen ROC-verband. Amsterdam: SCOKohnstamm Instituut.

Veldhoven, M. van, \& Meijman, T. F., (1994). Het meten van psychosociale arbeidsbelasting met een vragenlijst. De vragenlijst Beleving en Beoordeling van de arbeid (VBBA). (The measurement of psychosocial workload by means of a questionnaire. The Dutch questionnaire on the experience and evaluation of work). Amsterdam: Nederland institutuut voor arbeidsomstandigheden.

Walumbwa, F.O.,Wang, P.Lawler,J.L.Shi, K.(2004). Therole of collective efficacy in the relations between transformational leadership and work outcomes. Journal of Occupational and Organizational Psychology, 77, 515-530. doi: 10.1348/0963179042596441

West, M. A. (2002). Sparkling fountains or stagnant ponds: An integrative model of creativity and innovation implementation in work groups. Applied Psychology: An International Review, 51(3), 355-3. doi: 10.1111/1464-0597.00951

Winter, S. G. (1990). Survival, selection, and inheritance in evolutionary theories of organization. In J. V. Singh (Eds.), Organizational Evolution - New Directions (pp. 269297). Sage: Newbury Park, CA.

Yammarino, F. J., \& Dansereau, F. (Eds) (2009). Multi-level issues in organizational behavior and leadership. Bingley, UK: Emerald.

Zaccaro, S.J., Blair, U., Peterson, C., \& Zazanis, M. (1995). Collective efficacy. In J.E. Maddux (Ed), Self-efficacy, adaptation, and adjustment (pp. 305-328). New York: Plenum.

Zellmer-Bruhn, M. \& Gibson, C. (2006). Multinational organizational context: Implications for team learning and performance. Academy of Management Journal, 49 (3), 501-518. 



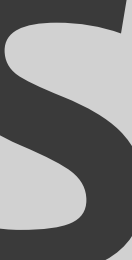

Summary in Dutch (Samenvatting) 


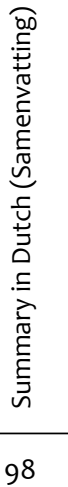


Docententeams waarvan de leden samen verantwoordelijk zijn voor het opleiden, begeleiden en kwalificeren van groepen leerlingen of studenten, worden steeds belangrijker in het Nederlandse onderwijs. Vooral in veel regionale opleidingscentra (ROC's) is het werken in teamverband de afgelopen jaren sterk gestimuleerd. Het ontwikkelen van docententeams wordt als een belangrijk instrument gezien voor het realiseren van de doeleinden van het competentiegericht onderwijs. Aangenomen wordt dat als groepen docenten intensief samenwerken en zich samen verantwoordelijk voelen, het beroepsonderwijs beter in staat is de benodigde competenties bij studenten te ontwikkelen en deze ontwikkeling af te stemmen op de leerbehoeften en mogelijkheden. Maar niet alleen in het onderwijsveld wordt het werken in teamverband steeds belangrijker gevonden. Ook in de onderwijskundige onderzoeksliteratuur worden de mogelijke voordelen van het werken met docententeams aangetoond. Zo bevordert werken in teams de ontwikkeling van het onderwijs, de begeleiding van studenten en de professionalisering van docenten. Echter, onderzoek toont ook aan dat als teams niet goed worden vormgegeven en niet goed worden begeleid in hun ontwikkeling, de kans dat ze goed gaan functioneren klein is. Docenten zijn vooral bezig met het primaire proces (lesgeven) en zijn gewend om daarin zo autonoom mogelijk te werken. Het delen van de onderwijsverantwoordelijkheden met collega's is nieuw voor docenten. Bovendien zijn docenten maar voor een deel van de uitvoering van hun werk afhankelijk van elkaar. Want ook al maken docenten deel uit van een team, een groot deel van hun tijd zullen zij nog steeds alleen voor de klas staan.

Tot op heden is nog weinig wetenschappelijk onderzoek gedaan naar teams in het middelbaar beroepsonderwijs. In dit proefschrift is nagegaan welke factoren kunnen leiden tot effectief functionerende docententeams in het middelbaar beroepsonderwijs. Het conceptueel model van deze studie -waarin de mogelijke relaties tussen een aantal geselecteerde teamen individuele kenmerken en teameffectiviteit zijn weergegeven- is gebaseerd op het klassieke Input-Process-Outputmodel (IPO), dat veelvuldig gebruikt wordt in onderzoek naar teameffectiviteit. In dit model vallen onder input bijvoorbeeld de kennis en vaardigheden van teamleden, de samenstelling van het team en aspecten van de organisatie die het teamwerken ondersteunen. Het proces behelst de uitwisseling van bronnen tussen teamleden, zoals kennis, informatie en expertise, en de aard van deze interactie. Onder output worden alle opbrengsten van teamwerken gerekend.

In een serie van vier empirische studies is onderzocht welke factoren essentieel zijn om te komen tot effectief werken van docenten in teams. In deze studies is de selectie en operationalisatie van factoren gebaseerd op de relevantie voor de specifieke onderwijskundige context van deze studie; namelijk het middelbaar beroepsonderwijs, waar het werken in teams nog maar recentelijk is gestart en voornamelijk gelegitimeerd wordt 
vanuit de doelstellingen voor competentiegericht onderwijs. Om deze reden is in de eerste verkennende studie door middel van interviews met afdelingsmanagers geprobeerd zicht te krijgen op deze context. In de interviews is ingegaan op vragen zoals wat er verstaan wordt onder teameffectiviteit binnen een ROC (output) en welke beïnvloedbare factoren in dit kader genoemd worden (hoofdstuk 2). Samen met de resultaten van een literatuurstudie vormde de interviews de belangrijkste input voor de drie kwantitatieve studies. In de eerste kwantitatieve studie onder bijna 300 docententeams (hoofdstuk 3 ) is het meest eenvoudigste model getoetst. Hiervoor is gekozen omdat de betreffende inputfactor in dit model, routine, de conceptualisatie van deze factor alsmede de relatie met teameffectiviteit nog onvoldoende uitgekristalliseerd was in de literatuur (zie Becker, 2008). De tweede en derde kwantitatieve studies (onder 50 docententeams) hadden tot doel de resultaten van de eerste kwantitatieve studie te valideren en het zogenoemde zuinige model verder uit te breiden met een beperkt aantal relevante factoren.

\section{Resultaten}

\section{Deel 1: verkennend onderzoek naar teameffectiviteit binnen ROC's}

Om teameffectiviteit in kaart te kunnen brengen is gevraagd aan afdelingsmanagers wat zij verstaan onder een effectief docententeam (zie hoofdstuk 2). Uit de interviews $(n=28)$ komt naar voren dat teameffectiviteit meerdere aspecten omvat. Ondanks de specifieke onderwijskundige context, bleken deze aspecten overeen te komen met de aspecten die in de organisatieliteratuur veel genoemd worden. Bijvoorbeeld volgens Hackman (1983) is teameffectiviteit onder te verdelen in opbrengsten in termen van daadwerkelijke prestaties aan de ene kant en affectieve houdingen van teamleden aan de andere kant. De afdelingsmanagers richten zich met hun definitie van teameffectiviteit op de prestaties van het team (bijvoorbeeld goed onderwijs, hoge slaagpercentages, laag aantal drop-outs en tevredenheid van de stakeholders zoals studenten en bedrijven). Daarnaast benadrukken de managers ook het belang van meegaan met onderwijskundige ontwikkelingen (veranderingsbereidheid, innovatief vermogen) en de bereidheid van docenten om samen te (blijven) werken in teams (levensvatbaarheid).

Volgens de managers zijn verschillende factoren essentieel voor effectief functionerende docententeams, namelijk de samenstelling van het team, de samenwerking in het team, het leiderschap en de helderheid en eenduidigheid van de doelstellingen van het team.

\section{Samenstelling van het team}

Het merendeel van de afdelingsmanagers heeft ervaren dat kleine docententeams effectiever zijn dan grote teams, omdat de coördinatie en planning van de werkzaamheden eenvoudiger 
is. Volgens de afdelingsmanagers bestaat een effectief team uit zes tot tien docenten en uit een mix van oudere en jongere en mannelijke en vrouwelijke teamleden. Niet alleen de groepsgrootte is van belang maar ook de kenmerken van de teamleden. Volgens de managers functioneren teams ook beter als de (onderwijs)visie en werkmotivatie van de leden niet te veel van elkaar verschillen. Dit laatste komt overeen met de studie van Crow en Pounder (2000) waaruit blijkt dat docenten uit een team met collega's in dezelfde loopbaanfase en met een overeenkomstige onderwijsvisie, minder moeite hebben met plannen, overeenstemming creëren, beslissingen nemen, coördinatie en gedeelde activiteiten. Er zijn echter ook studies waarin juist de voordelen van teams die samengesteld zijn uit leden met verschillende professionele achtergronden, kennis en vaardigheden worden beschreven (zie bijvoorbeeld Paulus, 2000; Somech \& Drach-Zahavy, 2007; West, 2002). Deze teams zullen meer innoveren dan teams waarin de leden minder van elkaar verschillen. De samenstelling van een team is van belang voor het functioneren ervan, maar het is nog de vraag welke samenstelling het meest effectief is; het lijkt erop dat voor het dagelijks functioneren en samenwerken een homogeen team het beste werkt, terwijl voor het innovatief vermogen juist een heterogene samenstelling van belang lijkt. In de kwantitatieve studies zijn enkele van deze teamkenmerken meegenomen als achtergrondvariabelen.

\section{Samenwerking in het team}

Uit de interviews blijkt dat zelfsturendheid (resultaatverantwoordelijkheid) een belangrijke voorwaarde is voor effectieve samenwerking. Bij zelfsturendheid gaat het om de mate van zelfstandigheid van het team. Het merendeel van de afdelingsmanagers geeft aan dat ze tevreden zijn over het zelfstandig uitvoeren van het onderwijs binnen de teams. Tegelijkertijd wordt er bij problemen vaak eerst naar de leidinggevende gekeken en niet naar hoe de teamleden het probleem onderling zouden kunnen oplossen. In de literatuur wordt het belang van 'group efficacy' in relatie tot de zelfsturendheid van een team aangegeven. Group efficacy is het collectieve vertrouwen in een team dat het goed presteert en problemen kan oplossen (zie ook Guzzo, Yost, Campbell \& Shea, 1993). Het vertrouwen in het eigen kunnen van het team is cruciaal om zelfsturend en succesvol te kunnen zijn. In de kwantitatieve studies (hoofdstuk 4 en 5 ) is de voorspellende waarde van group efficacy op teameffectiviteit onderzocht.

Verder blijkt uit de interviews dat de ontwikkeling van effectieve samenwerkingsverbanden en rolverdelingen van wezenlijk belang zijn voor het goed functioneren van een team. Deze coördinatie en samenwerkingsverbanden tussen teamleden wordt in de onderzoeksliteratuur vaak in verband gebracht met routines in teams. Routines zijn op te vatten als het vermogen van een team om adequaat te handelen in een bepaalde situatie. Routines ontstaan doordat een team docenten steeds opnieuw het werk op een gelijksoortige manier aanpakt. 
Binnen een taak wordt zoveel mogelijk voor hetzelfde alternatief uit de verzameling handelingen gekozen, wordt dezelfde volgorde van acties aangehouden en wordt dezelfde rolverdeling gehandhaafd. Teamleden zijn geneigd om zich te conformeren aan een bepaald handelingspatroon omdat in routines een rolverdeling is vastgelegd. Daardoor weten teamleden wat ze van elkaar kunnen en mogen verwachten, wat leidt tot effectief handelen. In de drie kwantitatieve studies (hoofdstuk 3, 4 en 5) van dit proefschrift is het routineconcept in relatie tot teameffectiviteit onderzocht.

Leiderschap en de helderheid van de doelstellingen in het team

Uit de interviews blijkt het belang van leiderschap voor het welslagen van docententeams. Ook al is zelfsturendheid van de teams het uiteindelijke doel, de implementatie van het werken in teamverband vraagt een verandering van de docenten. Leiderschap is belangrijk om deze verandering te faciliteren en te ondersteunen. Daarnaast is leiderschap van belang voor verkrijgen van gezamenlijke doelen. Volgens de afdelingsmanagers moet bij iedereen duidelijk zijn wat het team gezamenlijk moet realiseren. Ook Hackman, die zijn leven lang onderzoek deed naar teams, benadrukt in zijn boek 'Leading Teams' het belang van het hebben van leiderschap en een heldere richting (doel). Het bepalen van de doelen gebeurt vaak in samenspraak tussen het team en het management. De mate van betrokkenheid van het team bij het definiëren van duidelijk doelen is afhankelijk van de mate van zelfsturendheid. Het is belangrijk dat de leidinggevende het zelfsturende niveau van het team kent en hierop anticipeert. Wanneer het team nog maar kort samenwerkt, helpt de leidinggevende bij het bepalen van een richting. Voor een leidinggevende is het belangrijk dat hij of zij besef heeft van de stappen die een team moet doormaken. Ook is het belangrijk dit leerproces te kunnen ondersteunen en een team door de fasen heen te kunnen leiden. De rol van de leidinggevende moet voornamelijk gericht zijn op de ontwikkeling. Het team moet zichzelf bezighouden met de dagelijkse processen. Dit wordt in de literatuur aangeduid met transformationeel leiderschap. In de kwantitatieve studie (hoofdstuk 5) is gekeken naar de voorspellende waarde van transformationeel leiderschap op teameffectiviteit.

\section{Deel 2: Kwantitatieve studies}

De literatuur en de interviews laten zien dat routines, group efficacy en transformationeel leiderschap van invloed kunnen zijn op het effectief functioneren van teams binnen ROC's. In de drie kwantitatieve studies in dit proefschrift is daarom met behulp van Multilevel Structural Equation Modeling (MSEM), uitgevoerd in het softwareprogramma Mplus, gekeken naar de voorspellende waarde van de drie variabelen op teameffectiviteit en de onderlinge relaties tussen de variabelen. In de kwantitatieve studies wordt gebruik gemaakt van twee outputvariabelen: teamprestaties enerzijds en de levensvatbaarheid van het team - ook wel de wil van teamleden om in het team te blijven - anderzijds. 


\section{Het effect van routines op teameffectiviteit}

In hoofdstuk 3 staat het theoretische concept routines centraal. Uit onderzoek blijkt dat het routinebegrip een interessant concept is om teameffectiviteit te begrijpen. Routines worden gedefinieerd als terugkerende handelingspatronen die worden uitgevoerd door meer dan één persoon. Het routineconcept kan onderscheiden worden in twee onderdelen: een cognitief deel en een handelingscomponent. Dit onderzoek richt zich op het cognitieve deel dat de basis vormt voor collectieve handelingspatronen in teams. Voor het cognitieve deel van routines zijn verschillende operationalisaties en betekenissen in omloop. In deze studie is het gedefinieerd als 'gepercipieerde interdependentie'. Voor interdependentie is gekozen vanwege de wederzijdse afhankelijkheid tussen de teamleden die in het algemeen wordt gezien als voorwaarde voor routinevorming (zie bijvoorbeeld Becker, 2005). Dit onderzoek richt zich op taak- en relationele interdependentie. Taakinterdependentie betekent dat docenten van elkaar afhankelijk zijn voor het succesvol uitvoeren van hun werk. Maar vaak bepaalt ook de relationele interdependentie hoe docenten met elkaar omgaan en wat ze van elkaar verwachten. In hoofdstuk 3 is het directe effect van routines op teameffectiviteit onderzocht ( $n=1624$ docenten in 289 teams). Daarbij is specifiek gekeken naar de relatie tussen de twee vormen van interdependentie die belangrijk zijn voor routinevorming (taak- en relationele interdependentie) en twee type uitkomstmaten: teamprestatie en de levensvatbaarheid van het team. In lijn met onze verwachtingen vinden we dat routines in termen van taaken relationele interdependentie positief gerelateerd zijn aan de gepercipieerde effectiviteit van een team. Dit betekent dat het goed presteren van docententeams samengaat met teamleden die elkaar ook echt nodig hebben voor de uitvoering van het werk en samengaat met leden die goed weten wat ze van elkaar kunnen verwachten.

\section{De mediërende rol van group efficacy in de relatie tussen routines en teameffectiviteit}

Hoofdstuk 4 bouwt voort op hoofdstuk 3 door in een tweede steekproef te onderzoeken wat het effect van routines is op teameffectiviteit. Ook uit deze studies blijkt relationele interdependentie (routines) een significante positieve voorspeller te zijn voor teameffectiviteit, waarmee de relevantie van routines in relatie tot teameffectiviteit wederom wordt aangetoond. Er wordt geen bevestiging gevonden voor het effect van taakinterdependentie op teameffectiviteit. Deze samenhang werd wel gevonden in de eerste kwantitatieve studie. Een mogelijke verklaring hiervoor zou kunnen zijn dat het hier een kleinere respondentengroep betreft ( $n=450$ docenten in 50 teams). Verder is in dit hoofdstuk onderzocht of de relatie tussen routines en teameffectiviteit wordt gemedieerd door group efficacy. Group efficacy is gebaseerd op het self efficacy concept van Bandura (1982). Self efficacy is iemands vertrouwen in zijn/haar eigen capaciteiten om een bepaalde taak met succes te volbrengen. Group efficacy is het gedeelde vertrouwen onder alle teamleden dat 
het team goed kan presteren. Group efficacy is een flexibel construct dat verandert door bijvoorbeeld nieuwe kennis, feedback en ervaringen van teams. De verwachting was dat hoe sterker de routinevorming in een team, des te meer een collectief vertrouwen in het team ontstaat, waarmee de teameffectiviteit zal toenemen. Deze veronderstelling werd in dit onderzoek bevestigd voor relationele interdependentie (routines) en de levensvatbaarheid van het team (teameffectiviteit). Dit betekent dat willen docententeams goed presteren, teamleden moeten kunnen voorspellen wat de andere teamleden gaan doen en moeten kunnen anticiperen op het gedrag van een teamlid. Er is echter geen direct effect gevonden van group efficacy op teamprestatie, terwijl in ander onderzoek veelal een positieve relatie is gevonden tussen deze twee variabelen (zie bijvoorbeeld Peterson, Mitchell, Thompson, \& Burr, 1996). Behalve het bewijs voor een positief direct effect van group efficacy op teamprestatie zijn er ook bescheiden en complexe relaties gevonden tussen group efficacy en teamprestatie waarbij verschillende groepsprocessen interacteren (Campion, Medsker, \& Higgs, 1993; Earley, 1993; Guzzo, Yost, Campbell, \& Gregory, 1993; Prussia \& Kinicki, 1996). Uit eerder onderzoek blijkt bijvoorbeeld dat taakinterdependentie een interactieeffect heeft op de relatie tussen group efficacy en teamprestatie. De relatie tussen group efficacy en teamprestatie werd daarbij sterker, naarmate de taakinterdependentie groter was (de mate waarin teamleden van elkaar afhankelijk zijn om de taak te volbrengen). Dit komt omdat taakinterdependentie helpt bij het uitwisselen van informatie, wat weer van invloed is op group efficacy en de relatie met teamprestatie. In een onderwijscontext is taakinterdependentie niet vanzelfsprekend, omdat leraarschap voor een deel een autonoom beroep is en docenten niet gewend zijn om van elkaar afhankelijk te zijn. Dit impliceert dat het creëren van een hoge mate van taakinterdependentie mogelijk een goede interventie kan zijn in docententeams.

\section{Effect van transformationeel leiderschap, routines op group efficacy en teameffectiviteit}

De invoering van teams vraagt om verandering van docenten. Van docenten wordt verwacht dat ze meer dan voorheen samenwerken. De direct leidinggevende van docenten kan een belangrijke rol spelen bij deze verandering. Eerder onderzoek heeft aangetoond dat transformationeel leiderschap medewerkers kan stimuleren zich op de belangen van het team te richten in plaats van op hun eigen belangen, waardoor medewerkers bereid zijn harder voor het team te werken. De transformationeel leider stimuleert waar nodig de docenten elkaar op te zoeken en bevordert de ontwikkeling van teams. Daarom is in hoofdstuk 5 transformationeel leiderschap als variabele toegevoegd aan het conceptueel model uit hoofdstuk 4. In dit hoofdstuk is onderzocht of transformationeel leiderschap, routines en group efficacy van invloed zijn op teameffectiviteit. Dit hoofdstuk laat zien dat transformationeel leiderschap belangrijk is voor het effectief functioneren van teams. 
Als transformationeel leiderschap in het model wordt toegevoegd als input factor, blijkt de relationele interdependentie (routines) nog steeds een significante voorspeller te zijn voor teameffectiviteit. Hiernaast is in dit hoofdstuk onderzocht of de relatie tussen transformationeel leiderschap, routines en teameffectiviteit wordt gemedieerd door group efficacy. Deze veronderstelling werd wederom bevestigd voor relationele interdependentie (routines) en de levensvatbaarheid van het team (teameffectiviteit). Echter, de resultaten uit hoofdstuk 5 laten ook zien dat het effect van transformationeel leiderschap niet via group efficacy verloopt. Dit onderzoek richt zich op één onderdeel van transformationeel leiderschap: charisma. Vervolgonderzoek zou moeten uitwijzen of andere eigenschappen ten grondslag kunnen liggen aan de impact van transformationeel leiderschap op group efficacy, namelijk de visionaire eigenschappen van transformationeel leiderschap.

\section{Conclusie}

Dit onderzoek is verricht omdat veel ROC's inmiddels hun organisatie hebben ingericht op basis van een teamstructuur. Op dit moment is het zelfs doorgedrongen tot de collectieve arbeidsvoorwaarden. In het bijhorende statuut is daarover het volgende vastgelegd: “... In het $\mathrm{mbo}$ is het onderwijsteam de basis organisatorische eenheid..." (MBO-raad, 2009). Zoals blijkt uit het statuut hebben docententeams binnen ROC's de uitvoering van het onderwijs in handen. Onderwijs binnen ROC's vraagt dus om teamwerk. Uit dit proefschrift blijkt dat routines, group efficacy en transformationeel leiderschap van belang zijn om teams in te richten en te laten functioneren. 



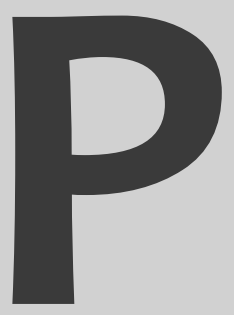

List of publications

(Publicaties en presentaties) 


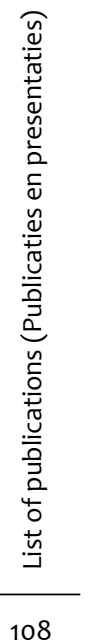




\section{Publicaties}

Truijen, K.J.P. (2011). Zelfsturing en samenwerken. Voorwaarden voor effectief functioneren van teams. Profiel vakblad voor de BVE-sector, 11, 32-34.

Nieuwenhuis, L.F.M., Hoeve, A., \& Truijen, K.J.P. (2011). Conceptualisation of routines as a carrier for innovation. In IPOB (Eds.), The future of knowledge-intensive service work. Theory and practice of managing human and organizational resources. Marburg: Metropolis.

Runhaar, P., Boswinkel, I., Bouwhuis, L., Sanders, K., Truijen, K., \& Yang, H. (2009). Innovatief gedrag van docenten. Hoe kan HRD-beleid innovatie bevorderen? Opleiding \& Ontwikkeling, $10,10-13$.

Truijen, K.J.P., \& van Woerkom, M. (2008). The pitfalls of collegial coaching: an analysis of collegial coaching in medical education and its influence on stimulating reflection and performance of novice clinical teachers. Journal of Workplace Learning, 20(5), 316-326.

Hoeve, A., \& Truijen, K.J.P. (2008). Leren op de werkplek: een model om zicht te krijgen op teamroutines. Opleiding \& Ontwikkeling, 5, 15-18.

Truijen, K.J.P., \& Woerkom, M. van (2006). De valkuilen van collegiale coaching. Een onderzoek naar coaching van beginnende docenten door ervaren collega-docenten op de werkvloer. Opleiding \& Ontwikkeling, 9, 11-14.

\section{Publicaties in voorbereiding}

Truijen, K.J.P., Sleegers, P.J.C., Meelissen, M.R.M., \& Nieuwenhuis, A.F.M. What makes teacher teams in a vocational education context effective: a qualitative study. (resubmitted Journal of Workplace Learning)

Truijen, K.J.P., Sleegers, P.J.C., Meelissen, M.R.M., \& Nieuwenhuis, A.F.M. Factors that influence team functioning in a vocational education context (submitted).

Truijen, K.J.P., Meelissen, M.R.M., Sleegers, P.J.C., \& Nieuwenhuis, A.F.M. Team effectiveness: the mediating role of Group efficacy in the relationship between Routines and Team effectiveness.

Truijen, K.J.P., Sleegers, P.J.C., Meelissen, M.R.M., \& Nieuwenhuis, A.F.M. Teams in scholen: ontwikkelen van teamwerken. 


\section{Presentaties op conferenties}

Hoeve, A., Smulders, H., \& Truijen, K. Verwachtingen van afdeling(school)managers over het functioneren van hun docententeams. Onderwijs Research Dagen, Leuven, 27-29 mei, 2009.

Truijen, K.J.P., Yang, H., Meelissen, M.R.M., \& Nieuwenhuis, A.F.M. An iceberg model of team routines: an integrative concept. Paper for the international Conference on Team working, Birmingham, 10-12 September, 2008.

Truijen, K.J.P., \& Nieuwenhuis, A.F.M. Interdependentie en routinevorming in roc's. Onderwijs Research Dagen, Groningen, 6-8 juni, 2007.

Truijen, K.J.P., Hoeve, A., \& Nieuwenhuis, A.F.M. Measuring organizational routine change in work teams. Towards a theoretical framework for studying organizational routine change. Paper for the third international Conference on Organizational Routines. Strasbourg, 25-26 May, 2007.

\section{Rapportage}

Hoeve, A., Smulders, H., \& Truijen, K. (2010). Monitor gedrags- en cultuurverandering ROC Midden Nederland. Ecbo. 


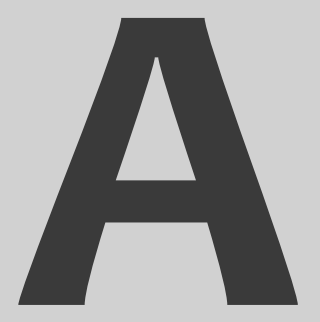

Acknowledgements in Dutch

(Dankwoord) 


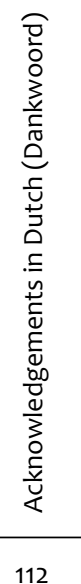


Het is zover, mijn proefschrift is af. Maar geen proefschrift zonder de steun van een aantal mensen die ik graag wil bedanken.

Mijn eerste promotor, Peter. Zonder jouw begeleiding was dit proefschrift er niet geweest. Je kwam midden in mijn onderzoek als vakgroepvoorzitter naar Twente en werd mijn eerste promotor. Ik wil je bedanken voor het vertrouwen dat je in mij gesteld hebt en de moeite die je gedaan hebt dit onderzoek 2,5 jaar geleden op te pakken. Als begeleider leerde je me in een korte tijd mijn focus scherp te houden en motiveerde je me steeds net dat stapje extra te doen. De voortgangsbesprekingen waren altijd nuttig, en jouw onconventionele uitspraken zorgden ervoor dat ik altijd met een lach de besprekingen verliet. In 2010 en 2011 heb je me de ruimte gegeven semiprofessioneel wielrennen te combineren met mijn onderzoek. Heel veel dank hiervoor.

Mijn tweede promotor, Loek. Zonder jou was het niet mogelijk geweest om te beginnen aan dit onderzoek en zou dit proefschrift niet zijn geschreven. Ik ben je dankbaar voor het vertrouwen, en voor de ruimte die je me gaf om mijn eigen invulling te geven aan het onderzoek.

Mijn co-promotor, Martina. Als begeleidster ben je betrokken en onmisbaar geweest bij mijn promotieonderzoek. Ik kon altijd bij je binnenlopen en je vond altijd tijd om constructief commentaar te leveren op mijn teksten en te sparren over nieuwe onderzoeksideeën. Heel veel dank hiervoor.

Mijn afstudeerbegeleidster, Marianne. Tot aan de laatste periode van mijn masterstudie ben ik in de veronderstelling geweest mijn loopbaan te beginnen in het bedrijfsleven, totdat ik mijn afstudeeronderzoek ging doen bij het UMC St Radboud, met jou als begeleidster. Marianne, jouw begeleiding en enthousiasme tijdens mijn afstudeeronderzoek naar coaching en docentprofessionalisering hebben me doen besluiten verder te gaan in het onderzoek. Ik wil je graag bedanken voor je bereidheid plaats te nemen in de promotiecommissie van dit proefschrift.

De studies beschreven in dit proefschrift hadden niet tot stand kunnen komen zonder de inzet van het ROC van Twente, Deltion College en het ROC Midden Nederland. In het bijzonder dank ik hiervoor Henk Ritzen. 
Ook was mijn onderzoek binnen ROC Midden Nederland er niet geweest wanneer ik vanuit het Expertisecentrum Beroepsonderwijs (ecbo) niet de mogelijkheid had gekregen mijn onderzoek te combineren met het onderzoeksproject: monitor gedrags- en cultuurverandering ROC Midden Nederland. Ecbo heeft me financieel de ruimte gegeven om mijn onderzoek te combineren. Hiervoor wil ik Aimee, Hester en José bedanken. Aimee, via Loek kwam ik met jou in contact. Onze besprekingen over het 'routine-concept' -eerst bij jou in Wageningen (stoas), later in Den Bosch (cinop) en Utrecht (ecbo)- waren erg leerzaam voor mij. Ik hoop dat we kunnen blijven samenwerken. Bedankt dat je mijn paranimf wilt zijn.

Mijn (oud) collega's van Onderwijskunde en EWI: bedankt voor de prettige samenwerking. Mijn kamergenoten Laura, Gerdy en Leandra, bedankt voor de afleiding en gezelligheid. Karlijn, jij bent degene die, buiten mijn begeleiders en Dannis om, mijn promotieonderzoek van dichtbij heeft meegemaakt. Bedankt dat je mijn paranimf wilt zijn.

Daarnaast wil ik de wielerclub Klein Verzet en triathlonclub Aloha van de UT bedanken voor alle trainingen. In het bijzonder wil ik Hanneke, Roland en Marco bedanken. Ik hoop dat we ook in de toekomst samen kunnen blijven trainen, want die Ironman moeten we nog wel een keertje doen!

Tot slot wil ik natuurlijk Dannis bedanken. Lieve Dannis, jouw betrokkenheid en humor hebben me op koers gehouden tijdens mijn promotie. Bedankt dat je voor mij nog even in Enschede wilde blijven en hier je werk hebt opgepakt. Op naar rondje “Beckum” op de P3!

Karin 

